\title{
EL "DESPOJO DE LOS CEMENTERIOS»: ORIGEN Y DESARROLLO DE LA SECULARIZACIÓN DE LA MUERTE EN CHILE Y LA CIUDAD DE CONCEPCIÓN (1871-1884)
}

\author{
POR \\ RUBÉN ELGUETA REYES ${ }^{1}$ \\ Universidad Católica de la Santísima Concepción / \\ Universidad de Concepción
}

\section{RESUMEN}

La muerte del coronel en retiro Manuel Zañartu Opazo en 1871, generó profundas molestias en el clero de la ciudad de Concepción tras fallecer sin los parámetros morales dispuestos por la Iglesia católica chilena de finales del siglo XIX. Pese a las prohibiciones de parte del obispo José Hipólito Salas para autorizar las exequias de Zañartu en el cementerio municipal de Concepción, los grupos liberales y la ciudadanía molesta con la actitud del obispo, irrumpió en el campo santo para proceder a los funerales. El proceso de secularización en Chile estaba desarrollando aperturas e inclusiones de las nuevas manifestaciones morales que disponían la figura del «ciudadano» como el centro de las preocupaciones del Estado, y un vector social de la incipiente «modernidad» en Chile.

PALABRAS CLAVE: secularización; muerte; liberalismo y conservadurismo.

\section{THE «DISPOSSESION OF CEMETERIES»: ORIGIN AND DEVELOPMENT OF THE SECULARIZATION OF DEATH IN CHILE AND THE CITY OF CONCEPCIÓN (1871-1884)}

\begin{abstract}
The death of Colonel Manuel Zañartu Opazo in 1871, generated deep discomfort in the clergy of the city of Concepción, because he died without the moral parameters arranged by the Catholic Church in Chile at the end of the 19th century. Despite the prohibitions from the Bishop José Hipólito Salas to authorize the funeral of Zañartu in the municipal cemetery of Concepción, liberal groups and citizens upset with the attitude of the Bishop. They introduce hard in to the cemetery for the funeral in memory of Colonel Zañartu. The process of secularization in Chile would be that as a result, it was developing openings and inclusions of new moral manifestations which had the idea of the «citizen» as the principal concerns of the Chilean State, as a social major boost of modern ideas in Chile.
\end{abstract}

KEY WORD: Secularization; Dead; Liberalism and Conservatism.

Cómo CITAR ESTE ARTículo / CITATION: Elgueta Reyes, R. 2018. «El ‘despojo de los cementerios': origen y desarrollo de la secularización de la muerte en Chile y la ciudad de Concepción (1871-1884)». Hispania Sacra 70, 142: 629-648. https://doi.org/10.3989/ hs.2018.043

Recibido/Received

19-07-2014

Aceptado/Accepted
30-07-2014

\footnotetext{
1 rubenelgueta@ucsc.cl / ORCID iD: http://orcid.org/0000-0002-4698-2922
} 


\section{INTRODUCCIÓN}

La secularización de los cementerios en Chile fue uno de los principales acontecimientos que dieron por resultado el impulso y arraigo de las leyes laicas durante la segunda mitad del siglo XIX. Frente a este respecto se ha escrito bastante, sin embargo, el análisis que se ha realizado del origen en sí del conflicto y la secularización de los cementerios en Chile, no ha tenido mayores revisiones por la historiografía que no sea enunciar la muerte del coronel Manuel Zañartu Opazo en 1871, y la negativa del obispo de Concepción ante la autorización de sus exequias. El análisis y el impacto mediático del hecho tampoco ha sido plenamente examinado desde la nueva historia cultural, aspecto que posee más consecuencias que las ya tradicionalmente enunciadas. A partir del presente artículo, se pretende efectuar un análisis más actualizado del conflicto en cuestión, examinándose nuevos antecedentes presentes en la prensa chilena entre 1871 y 1872, además de la documentación existente en el Archivo del Arzobispado de Concepción.

El marco histórico que envolvió el conflicto aquí presentado obedeció al de la secularización presente en Chile desde la segunda mitad del siglo XIX en adelante. Sin embargo, será comprendido en función de los procesos históricos y culturales inmersos en un país que conformaba una "nueva república», en cuya búsqueda de proyecto nacional estaban las pretensiones de elevar la figura del ciudadano por "sí mismo»", antes que por su convicciones religiosas, las cuales lejos de pretender eliminarlas del orden público comenzaban a vincularse al ámbito privado. Pese a este interés creciente en la idea de ciudadanía, esta debe comprenderse en el marco reducido que para su tiempo consignaba esta figura, apuntando al varón con una posición social acomodada que además pertenecía a la elite.

La muerte no estaba ausente de la secularización. La cosmovisión estatal y católica del deceso ocasionó divergencias claves ante la idea de situar a los difuntos fallecidos fuera de los parámetros deseables para el catolicismo - principalmente, a los muertos impenitentes o sin bautismo- por fuera de los espacios de la muerte en lo sagrado, ello, en obediencia a las disposiciones católicas del siglo XIX. La modernización en la muerte comenzaba a posicionarse gradualmente en la sociedad occidental. La vida se prolongaba gracias a los adelantos en la medicina, y en el contexto social, el deceso fue distanciándose de la intimidad familiar para acontecer en la cotidianidad del hospital. Philippe Ariès sintetiza esta modernización de la muerte en occidente estableciendo que: «[...] retrocedió y dejó la casa por el hospital: está ausente del mundo familiar cada día. El hombre hoy, al no verla con la suficiente frecuencia y de cerca, la ha olvidado: se ha vuelto salvaje, y pese al aparato científico que la envuelve, crea más trastornos en el hospital, centro de la razón y la técnica [...]». ${ }^{2}$ Este cambio que describe Ariès, permite reconocer las metamorfosis de la muerte en Europa para finales del siglo XIX, sin embargo, esta realidad en vicisitud, distante del contexto chileno, todavía no se concretaba plenamente en la ciudad de Concepción o dentro del contexto latinoamericano, sin embargo, avanzaba en dicha dirección histórica y cultural.

\footnotetext{
1 Jakcsić y Serrano 2011: 200-206.

2 Ariès 2000: 258.
}

Más allá de la presencia o no de un médico asistiendo el deceso, la figura del sacerdote que otorgaba la extremaunción era un aspecto característico de la muerte en el católico. Tras el inminente fallecimiento de Manuel Zañartu Opazo, se aprecia la negativa del mencionado coronel por adherirse a las reclamaciones de la Iglesia, las que consistieron en proporcionar la bendición y unción de los santos antes de su fallecimiento. Lo anterior ocasionará el gran conflicto de los cementerios en Chile tras sepultarse un cadáver corrompido, en parte del territorio sagrado, traduciéndose en no recibir el perdón y morir en el pecado junto con la corrupción del campo santo; ello, en el caso hipotético de que el "cadáver impenitente» lograse llegar a su sepultura.

La situación desatada por el obispo Salas se habría constituido en la piedra angular de todo un enfrentamiento político hasta la promulgación de la Ley de Inhumación de Cadáveres (1883), aprobada en el gobierno del presidente Domingo Santa María y publicada en el Diario Oficial el 2 de agosto de 1883. Los principales aportes desarrollados frente a esta temática en particular, proceden de los historiadores Fernando Campos con su Historia de Concepción 1550-1988 (1989), Margarita Fernández con su trabajo Historia del Cementerio de Concepción desde 1823 hasta la actualidad (1989), Ricardo Donoso con Las ideas políticas en Chile (1946), Marco A. León con su trabajo Sepultura sagrada tumba profana los espacios de la muerte en Santiago de Chile 1883-1932 (1997), entregándose en este último ejemplo, un análisis de las problemáticas de los cementerios en forma detallada y con una lectura problemática más actualizada que en los casos anteriores. Frente a los autores mencionados, Fernando Campos establece que ante el fallecimiento del coronel Manuel Zañartu ${ }^{3}$, se desarrolló una escalada de reclamaciones por parte de las voces disidentes al pensamiento de la Iglesia. Al respecto, Campos establece:

El radicalismo penquista, los liberales avanzados, organizaron una campaña que reclamaba la laicización de las instituciones y restar a la Iglesia su definitiva intervención en la organización legal de la familia. El problema se extendió a nivel nacional. El acuerdo de cámara fue aprobado por 45 votos contra 27 de los conservadores. ${ }^{4}$

Pese a que el historiador describe y/o atribuye la acción liberal y radical a los empeños de sepultación para el coronel Zañartu, no existe una distinción clara en torno a las diferencias de ambas cosmovisiones del problema. Se asume un discurso en el que no se entrega algún resquicio significativo en torno a la distinción de ambas ideologías políticas. La postura liberal podría resumirse en una separación gradual entre los poderes del Estado y la Iglesia, a diferencia del pensamiento

\footnotetext{
3 Manuel Zañartu Opazo fue un militar destacado en el transcurso de la Independencia. Posterior a su retiro, desempeñó diversas funciones en el servicio público de Concepción, destacándose principalmente en la Sociedad de Beneficencia, organización que estuvo a su cargo algunos meses antes de fallecer; trabajó en el municipio, y fue miembro activo de la masonería penquista. Su figura fue ampliamente respetada por la elite de Concepción, pues Zañartu era el único veterano de guerra hacia la década de 1870 que había disputado y logrado la Independencia de Chile con las condecoraciones propias de su rango. En sus ideas políticas destacó su adherencia a la corriente radical.
}

4 Campos 1989: 277. 
radical, que eventualmente apuntará a una separación total, más abrupta, entre ambas instituciones. ${ }^{5}$ Una característica fundamental del liberalismo en Concepción, según Fernando Campos Harriet, se expresó en su rasgo elitista, que inclusive tendría alcances de opositor, pero que a diferencia del radicalismo, los liberales habrían sido más que nada un cuerpo doctrinario por no funcionar como un partido político propiamente tal. Distinto es el caso de los radicales, quienes ya en 1859 estaban fundando su partido, sin embargo, las directrices generales más su organización se situaban principalmente en Santiago. ${ }^{6}$

Adicionalmente, el problema conceptual según lo entiende Fernando Campos H., es más bien desde la perspectiva legal, pues asume que las consecuencias del conflicto en torno al deceso de Zañartu habrían ocasionado la laicización de los cementerios. Hablar exclusivamente de laicización no permite comprender la magnitud que implicaba el componente cultural en sí mismo. No fue solo una separación desde la perspectiva legal, fue además, una secularización, por cuanto culturalmente se buscaba disminuir la injerencia de la Iglesia para que personas de otros credos religiosos - a los cuales se deben incluir a los protestantes, agnósticos y ateos, que poseían propiedades para sus sepultaciones en el cementerio de Concepciónpudiesen tener acceso a su sepulcro una vez acontecido el deceso, sin las arbitrariedades que imponía la administración eclesiástica frente a estos casos. La interpretación de la muerte comenzaba gradualmente a modernizarse en la cultura chilena de mediados del siglo XIX.

Margarita Fernández afirma que el problema central ante el deceso de Zañartu y sus exequias, radica en que se procedió en un cementerio de carácter público y no en un lugar apartado según lo entendía la Iglesia mediante el Derecho Canónico. En cuanto al contexto decimonónico, en lo público, la Iglesia católica detentaba amplias atribuciones. Sin embargo, el trasfondo que convulsionó más los ánimos, según Fernández, se habría ocasionado en el manejo de la información por parte del Gobierno:

Como el discutido Coronel había sido sepultado en el Cementerio de Público pero no en lugar apartado como la Iglesia entendía, el Obispo Salas [...] dirigió [José H. Salas] una nota al Gobierno reclamando por el atropello; pero este ofició al Intendente de Concepción para saber exactamente qué había pasado y al tener la contestación, en vez de dirigirse al Obispo [...]. ${ }^{7}$

A la situación suscrita, Fernández añade que se habrían abolido por decreto las leyes eclesiásticas en torno a la administración de los cementerios, siendo estas materias en adelante, atribuciones de las juntas de beneficencia como entidades administrativas. Las consecuencias del proceso fueron claras, «[...] se arrancó la Cruz de las sepulturas y se permitieron las ceremonias gentiles y los ritos masónicos». ${ }^{8}$

La secularización de los cementerios, a raíz del fallecimiento de Zañartu, parecía tomar directrices opuestas al catolicismo más tradicional y su "exclusivismo» de los ritos mortuorios, ya sea desde la perspectiva de la religiosidad

\footnotetext{
5 Collier 2005: 278-279

6 Ídem.

Fernández 1989: 57

8 Ídem.
}

popular, como por efectos de la laicización del Estado de Chile. Al respecto, interesa hablar de secularización, por tratarse de un proceso cultural que además de lo jurídico, comprende las motivaciones religiosas de los habitantes en Concepción. Es por ello que la perspectiva teórica aportada por M. León para tratar la temática de los cementerios, resultan esenciales ante la necesidad de ampliar la mirada historiográfica del conflicto. ${ }^{9}$ La secularización como proceso histórico con una raigambre cultural, es comprendida en la presente investigación como el antecedente previo de la modernidad; en consecuencia, se asume como la transformación cultural que va relegando lo religioso a una dimensión privada, quedando atrás el exclusivismo católico en la inferencia pública de los asuntos concernientes al Estado. Los imaginarios sociales se proyectan a una realidad más heterogénea, recayendo en una complejidad que va posicionando a los sujetos históricos frente a nuevas perspectivas transformadoras de la cultura tradicional ${ }^{10}$; para efectos del presente estudio, centradas en la muerte.

Pese a que las fuentes escritas hablan expresamente de la secularización más que una laicización, Margarita Fernández, Fernando Campos H., entre otros autores, persisten en el reduccionismo de solo analizar el problema desde una perspectiva legal, en circunstancias que la realidad histórica reviste mayor complejidad. Margarita Fernández

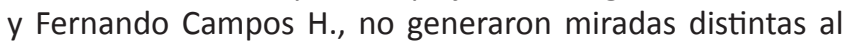
conflicto a las realizadas por Ricardo Donoso en Las ideas políticas en Chile (1946). Son historias que desarrollaron una mirada concéntrica, sin analizar los procesos descritos en función del contexto histórico acaecido en el resto del llamado Chile Republicano.

René Louvel expuso las disposiciones de la Iglesia ante el conflicto. Contrario a lo que se podría esperar, luego de la aprobación del proyecto de ley de Domingo Santa María en 1883 que solicitaba expresamente la secularización de los cementerios, el arzobispo de Santiago liberaría a la Iglesia de la administración de los cementerios públicos, sin embargo, con esa medida se resucitaba una costumbre anterior: el volver a sepultar a los católicos en los templos. Al respecto, Louvel señala:

Por su parte, el arzobispo de Santiago, como una consecuencia de lo anterior, dictó, a su vez un decreto [en el año 1883] execrando los cementerios fiscales o municipales, y desde ese momento, los párrocos dejaron de expedir los permisos para la sepultación de los católicos, quienes, en esta forma, volvían a ser enterrados en las iglesias [...]. ${ }^{11}$

Además de las investigaciones ya mencionadas, es necesario examinar el trabajo de Alfredo Palacios Roa que centra su investigación en la presencia de la Masonería tras la secularización de la muerte en Chile, más su actuar en el deceso de Zañartu. Al respecto, destaca la responsabilidad del Intendente Manselli, un amigo personal del coronel, quién desarrolló la tramitación necesaria para efectuar las exequias desconociendo la prohibición eclesiástica. Al respecto, Pala-

9 León 1997: 42-52

10 Kaufmann Salinas 2014: 27-49.

11 Louvel, R. "Apuntes para la Historia del Cementerio de Concepción 1846-1890», documento inédito del Archivo Sala Chile, Biblioteca Central, Universidad de Concepción. 
cios afirma: «[...] don Francisco Manselli, amigo de Zañartu, y amparado por los miembros de la Logia Fraternidad de Concepción, ordenó inhumarlo en la tumba de su familia, con todos los honores prescritos en la Ordenanza militar».12

En medio de este contexto de radicalismo y liberalismo, la enérgica y joven figura del obispo José Hipólito Salas pretendía imponer una mentalidad negativa y antirreligiosa de la masonería en general. La coyuntura política secularizadora de 1871, acompañada del creciente capitalismo mercantil en Concepción - contexto histórico en el cual, aparece la inmigración extranjera con ideas renovadas - habrían constituido una influencia importante para que los ciudadanos penquistas desarrollaran simpatías por las ideas radicales. Esta apertura a "lo nuevo», habría direccionado a una porción relevante de los penquistas del siglo XIX a una perspectiva crítica de la sociedad, distinta a la deseada por el obispo Salas. Las consecuencias inmediatas habrían sido el desprestigio del clero local por parte de sus detractores, y la polarización del ambiente social entre el conservadurismo y el liberalismo. Pese a las álgidas publicaciones en la prensa, el obispo Salas y sus detractores presentes en la masonería y el liberalismo más avanzado, procuraron tener un trato afable en los distintos espacios públicos de encuentro en la urbe.

Frente al problema de los cementerios, y desde una perspectiva sucinta del tema, los autores hacen referencias al problema legal, sin embargo, queda pendiente el análisis del impacto mediático que tuvo en Concepción la muerte del coronel Zañartu, además de las disposiciones prohibitivas del obispado para su posterior sepultación. Lo anterior desarrolló aspectos estratégicos que por medio de esta investigación se pretenden auscultar en cuanto a sus directrices generales. Solo existen exiguas diferencias entre un planteamiento y otro, ello implica volver a revisar las fuentes, aportar elementos de las revisiones enfocadas desde perspectivas que no hayan sido consideradas previamente, como por ejemplo, la representatividad liberal y conservadora en los discursos de la prensa decimonónica.

Hacia el año 1870, Zañartu se encontraba retirado de sus obligaciones militares, sin embargo, estaba dedicado a las ocupaciones políticas y cívicas de la ciudad. Al igual que en sus hazañas militares, Zañartu se destacó por su dedicación e irrestricto compromiso, desarrollando una activa carrera en la administración pública llegando a ocupar el cargo de presidente de la Sociedad de Beneficencia penquista por un lapso de tiempo previo a su enfermedad que lo llevaría a la muerte. ${ }^{13}$ Pese a que no se tenga registros consistentes de su actividad política, tuvo inclinaciones claras al radicalismo, convicción ideológica que estaba proliferando en toda la elite más liberal de Concepción. La vinculación de Zañartu con la masonería lo mantuvo cercano al laicismo, sin embargo, siempre fue un creyente católico aun cuando no participaba con frecuencia en la Iglesia.

En cuanto a su vida familiar, el coronel era casado, sin embargo, no vivía con su esposa legítima dado a que dicha

\footnotetext{
12 Palacios Roa 2006: 120.
}

13 A partir de la información presente en el Archivo de la Beneficencia de Concepción, únicamente ha sido posible encontrar algunos períodos entre los años 1870-1871, en el último año únicamente hasta el primer trimestre. Pese a la poca claridad de la información que presenta el archivo respecto del coronel Zañartu, se estima su vinculación con la institución en un año y tres meses. relación desde hacía tiempo se encontraba quebrantada. La condición moral y social ya descrita llevó a Zañartu a ser objeto de recriminaciones por parte del clero, pues se conocía por los círculos más influyentes del Concepción de 1870 que el coronel convivía con su amante. La inconveniencia moral que aquejaba a Zañartu según la Iglesia, sería la motivación principal que obligó al obispo Salas a impedir la sepultación del coronel en el Cementerio Municipal de Concepción, ello, tras la negativa del coronel ante los constantes llamados de atención emanados por parte de la Iglesia para que pudiese trasladarse al hogar de sus primeras nupcias. Esta ordenanza era un requerimiento urgente desde la perspectiva eclesiástica, pues la enfermedad de Zañartu se agravaba con el transcurrir de los meses. El obispo Salas preveía que el desenlace fatal sería inminente.

La negativa de Zañartu no fue un impedimento para los homenajes públicos hacia su venerada figura tras el desenlace fatal. Acompañado del impacto emocional en los habitantes de Concepción al darse a conocer la muerte del coronel héroe de la Independencia, los ánimos se agitaron fuertemente al conocerse la negativa del obispo Salas por no acceder a la autorización de sus exequias, situación interpretada como un agravio a una figura tan trascendental para la historia republicana de la ciudad de Concepción. La Iglesia sería la institución más afectada tanto en lo legal como en su prestigio, marcándose una fisura política que la situará en un segundo plano y en el desprestigio social entre los habitantes de Concepción impregnados del liberalismo decimonónico. La secularización de la cultura se estaba abriendo camino entre las ideas que circundaron las mentes de la elite penquista. El siglo XIX ante este respecto, parecía anunciar nuevos horizontes de modernidad ante la pretensión que le interesaba preservar a la Iglesia católica, la cual profesaba una religión cimentada en lo público porque, «[...] proporciona el componente moral a la obediencia política y legitimidad al ejercicio del poder político.... ${ }^{14}$. En el transcurso de la segunda mitad del siglo XIX en Chile, el Estado se fue desprendiendo en forma paulatina de su rol misionero. Fue avanzando hacia una apertura de las preocupaciones ideológicas del liberalismo en torno a la ciudadanía, la cual ocupó el sitial preferente de los intereses del Estado.

Si bien es evidente que la muerte impenitente del coronel Manuel Zañartu no podría haber sido el origen en sí mismo de la secularización de la muerte en Chile, la cual como proceso histórico era más amplia de tratar, el acontecimiento sí resultó ser emblemático y representativo del contexto en el que se encuentra inserto. Fue la muerte en disidencia una de las necesidades de atención trascendentales que el Estado chileno debía comenzar a resolver, pues la presencia de inmigrantes europeos ${ }^{15}$ con religiones disidentes al catolicismo, más la propia postura agnóstica de muchos de sus habitantes, coadyuvaron a la necesidad de ampliar las sepultaciones a un plano mayor al suscrito por la Iglesia católica chilena. Desde 1860 en adelante, las actividades mercantilistas fueron acaparando la atención de empresarios e inmigrantes que gracias a los puertos de Valparaíso y Talcahuano, arribaron con el interés de realizar nuevos

\footnotetext{
14 Castillo Rojas 2014: 226.

15 Estefane Jaramillo 2004: 56-59.
} 
negocios e instalarse en Chile. El impacto cultural que estos «nuevos chilenos» comenzarían a generar, incluían desde luego sus costumbres del país de origen.

\section{LA FIGURA HISTÓRICA DEL OBISPO SALAS}

El Dr. José Hipólito Salas fue el obispo que estuvo a cargo del obispado de Concepción entre los años 1853 y 1883. Su experiencia académica en el decanato de la desaparecida Facultad de Teología de la Universidad de Chile, un año antes de su llegada a Concepción, lo facultaron para la reapertura del Seminario de Concepción en 1852, espacio de formación de clérigos que se encontraba cerrado desde los tiempos de la Independencia.

Entre los estudios más actualizados de la vida y el pensamiento del obispo Salas, se encuentra el trabajo desarrollado por Andrés Medina, el cual se titula: Monseñor José Hipólito Salas Obispo de Concepción, Coraje y coherencia de la Fe (1997). A juicio de Medina, se debe tener cuidado al abordar el pensamiento del obispo -mucho menos, cometer el error de actualizar su pensamiento- por cuanto hacerlo, podría implicar la descontextualización histórica de su figura. Al respecto, el autor establece:

No es posible forzar una actualización del pensamiento ni de la acción desarrollada por el Obispo penquista; hacerlo implicaría manipularlo y descontextualizarlo en relación con el medio ambiente en el que se desenvolvió. Sin embargo, a través de la defensa que realizó para impedir el desplazamiento de los grandes valores inmersos en el catolicismo [la secularización] que por definición no son mutables en el tiempo por corresponder a una naturaleza eterna moldeada por la divinidad-, podemos evaluar la relevancia de su actuación, como también las consecuencias morales y éticas que derivaron a las opciones elegidas por las fuerzas en pugna en el seno de la sociedad decimonónica. ${ }^{16}$

Frente a los planteamientos de Medina, las observaciones que se debiesen señalar es que el historiador debe ser crítico de su pasado, problematizarlo, y establecer las posibles respuestas a la pregunta por ese pasado, por tanto, una visión crítica siempre es necesaria. No será posible captar por parte del historiador el pasado total. No existe un geometral que permita al historiador visualizar todas las realidades, ante tales dificultades, rescatar la figura del obispo Salas implica necesariamente un ejercicio de descontextualización en el sentido que se invoca el pasado especulando ${ }^{17}$, y desde un presente que necesariamente condiciona a la creación de un conocimiento indirecto, propio de una disciplina como lo es la Historia.

El segundo aspecto tratado por Medina: «los grandes valores inmersos en el catolicismo [...] que por definición son inmutables.... ${ }^{18}$, también corresponden a una inconsecuencia axiológica con el devenir histórico de los valores religiosos. Si hay algo que cambia más en la historia, es justamente la interpretación valórica de la sociedad. Ni la Iglesia, así como cualquier otra institución, pueden ser estáticas desde la perspectiva valórica al dinamismo del contexto histórico y

\footnotetext{
16 Medina 1997: 17.

17 Veyne 1984: 9-179.

18 Medina 1997: 17.
}

FIGURA 1

\section{Dr. José Hipólito Salas y Toro}

(Fotografía presente en la portada de su libro Los Cementerios, Imprenta Nacimiento)

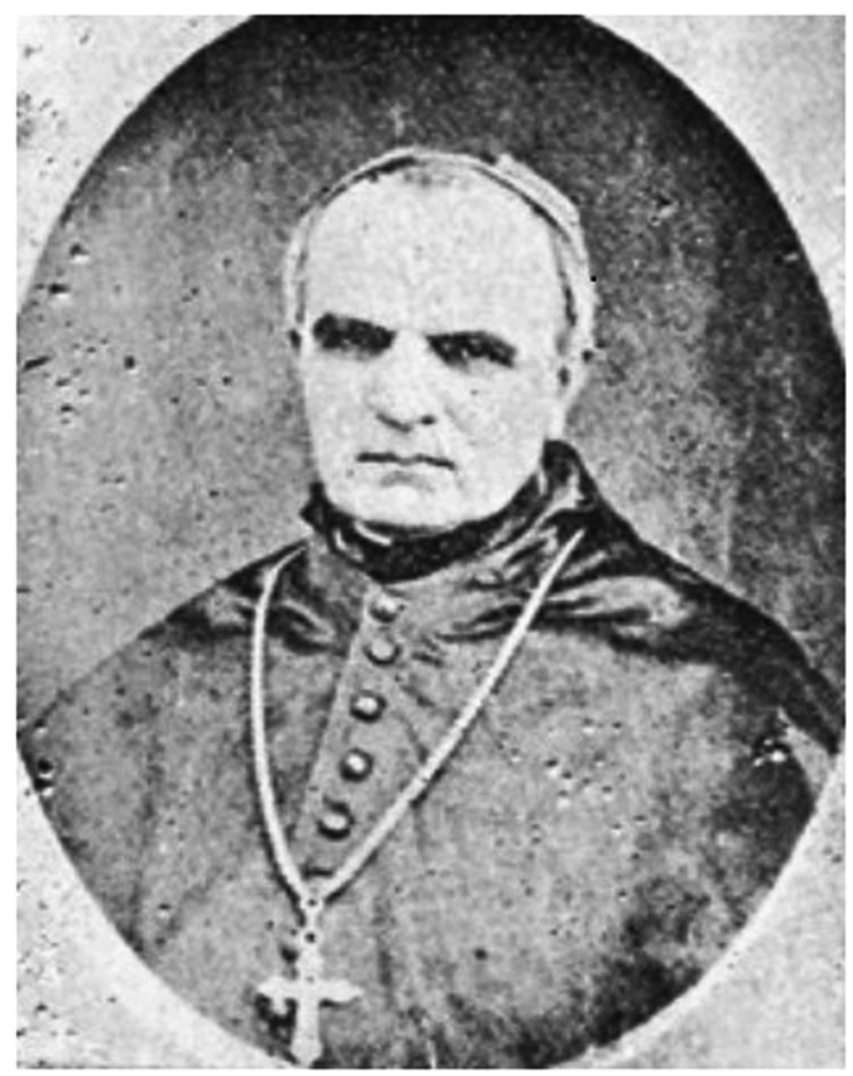

cultural. El historiador especializado reconoce que existe una historia de las mentalidades preocupada de las formas de pensar, igualmente, una historia de la cultura que se cimenta en las formas de concebir una o varias concepciones valóricas; lo cultural es a juicio de nuestra perspectiva, una alternativa mucho más compleja y necesaria de sistematizar. En cuanto a los postulados de Andrés Medina, que si bien son útiles para efectuar un primer acercamiento a la figura del obispo Salas, más la percepción de la curía penquista en torno a la secularización, constituye un trabajo que si bien idealiza la figura histórica de José $\mathrm{H}$. Salas, sí permite establecer un primer acercamiento a las fuentes que dan cuenta de su pensamiento y actuar en la administración del Obispado de Concepción.

Previo al conflicto tras el deceso del coronel Zañartu, el obispo Salas tuvo que intervenir ante la detención de José María de la Fuente, párroco de Arauco, acontecida en julio de 1861. La situación no era distinta a la que Salas debería resolver con Zañartu, pues de la Fuente amonestó a una pareja por vivir en público adulterio. La desavenencia pasó a mayores cuando la pareja se quejó ante el gobernador Pedro Martínez, quien citó al párroco de la Fuente para que explicara ante la autoridad los acontecimientos denunciados por la pareja; frente a la negativa del párroco de Arauco de compadecer ante la autoridad civil, este fue tomado prisionero por orden del gobernador, situación que molestó profundamente al obispo Salas, quien dirigió una carta en la cual, anuló toda la gestión efectuada por parte 
del gobernador, indicando que las facultades de suspender al sacerdote José María de la Fuente no le competían más que al obispo de Concepción.

La actitud del clérigo José de la Fuente, a juicio de Salas, habría sido la correcta, pues el párroco de Arauco actuó conforme a las disposiciones canónicas existentes en materias de adulterio. ${ }^{19}$ Según Fidel Araneda, la carta de molestia escrita por Salas ante la gestión del gobernador de Arauco - la cual, tenía por destinatario al ministro de culto de la época- en parte de sus líneas, se deja en evidencia un atropello a la autoridad eclesiástica. En parte de su queja, el obispo de Concepción planteó lo siguiente:

Desaciertos, arbitrariedades y violencia como la del gobernador de Arauco dejan en el corazón de los pueblos hondas huellas de descontento y malestar. El respeto debido a la autoridad se pierde con el torpe abuso que hacen de ellos sus depositarios y cuando los sañudos golpes de un poder subalterno caen sobre los Ministros de la Religión, el mal es de fatales consecuencias. Para mí la autoridad no gana, sino que pierde inmenso terreno con gobernadores tan violentos $y$ arbitrarios como Pedro Martínez. ${ }^{20}$

Este tipo de acontecimientos en conjunto con el evidente malestar del obispo Salas, fueron debilitando cada vez más la relación estrecha y armoniosa entre el Estado chileno y su Iglesia a nivel local. Así mismo, fueron conducentes a que el obispo se fuese inmiscuyendo cada vez más en la política, hasta convertirse a mediados de la década de 1870 en todo un estratega político del conservadurismo penquista, concentrándose en un activismo político exacerbado por las odiosidades y recriminaciones que él mismo criticaba en calidad de obispo y pastor de la feligresía. Animosidad negativa que también alcanzó niveles álgidos de parte de liberales, radicales, e inclusive algunas facciones partidarias de la Alianza Liberal-Conservadora que habían elegido por presidente de la República al liberal Federico Errázuriz Zañartu en $1871 .^{21}$

Más allá de las actividades políticas del obispo Salas, estas deben comprenderse en función del contexto histórico y cultural de la pretensión pública que desarrolló la Iglesia católica chilena, institución que sostuvo, como ya se mencionó, una clara visión de fe en el marco de lo público. A partir de este antecedente, el obispo Salas expresó su fervor y celo ante la necesidad de responder a dicho propósito, pues los valores tradicionales del catolicismo de la segunda mitad del siglo XIX esgrimían en su acometido la firme convicción que, la religión oficial del Estado chileno era exclusivamente la católica, siendo ella la responsable de la situación moral del ciudadano y del habitante en todo el territorio chileno. Al respecto, la Constitución Política de 1833, vigente por aquel tiempo, establecía: «La Religión de la República de Chile es la Católica Apostólica Romana; con exclusión del ejercicio público de cualquier otra». ${ }^{22}$ Para los seguidores de otras religiones, a quienes se les conoce como "disidentes», quedaron conminados por las circunstancias a ejercer sus cultos religiosos en forma privada.

19 Araneda 1963: 77-78.

20 "Carta del Obispo José Hipólito Salas dirigida al Ministro de Culto» el 26 de Julio de 1862, ibídem: 78.

21 Ibídem: 70-85.

22 Constitución Política de 1833, artículo 5.
La enigmática figura del obispo José Hipólito Salas podría definirse ante este respecto, como un clérigo sumamente riguroso en materia doctrinal, $y$, del mismo modo, un pastor de almas y formador de sacerdotes profundamente respetado por la Iglesia y sus feligreses más cercanos. En materias vinculadas a la desavenencia con el poder político local, ellas se explican por el exhaustivo trabajo que demandaba la responsabilidad de conducir espiritual y administrativamente al obispado de Concepción, en un período histórico de reformas legales y de incipiente apertura a la modernidad.

La Iglesia chilena ante este complejo escenario, debía disponer en sus cartas pastorales toda clase de énfasis para evitar que el cuestionamiento racional que circulaba por la prensa pudiese afectar a la fe de los católicos. Como herramienta de resguardo ante la formación religiosa de los chilenos, el propio obispo Salas en conjunto con el arzobispo de Santiago, Rafael Valentín Valdivieso y otros ilustres clérigos de su tiempo, manifestaron la necesidad de realzar la educación religiosa en 1874 , todo ello en pleno desarrollo del conflicto por las Leyes Laicas. Al respecto, el mensaje pastoral señala lo siguiente:

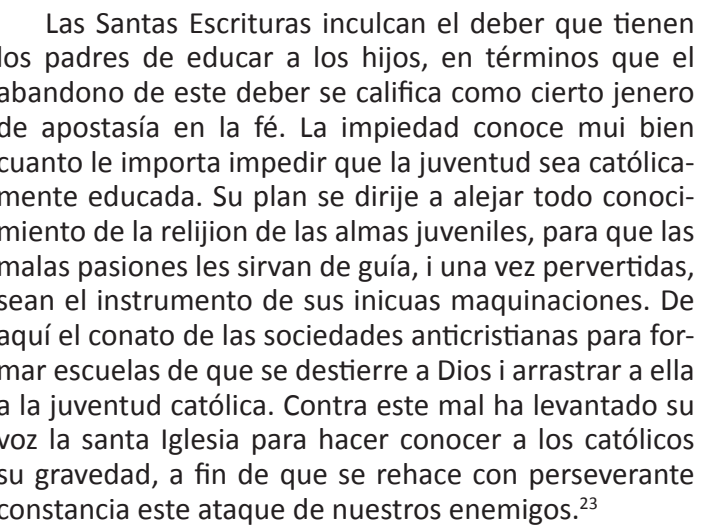

El elocuente llamado para perfeccionar la educación religiosa fue para el obispo Salas, más los clérigos suscritos, una forma de respuesta plausible ante las voces críticas y «enemigas» levantadas en contra de la Iglesia. Se reafirma ante este respecto que la religión católica en Chile era la responsable de conducir moralmente a los chilenos, y, en consecuencia, su influyente cosmovisión cultural se marcaba profundamente en la «identidad chilena». ${ }^{24}$ En tales circunstancias, las funciones del obispo Salas conllevaron a plasmar estas prácticas a buen recaudo en los feligreses bajo a su alero.

\section{EL DECESO dE MANUEl ZAÑARTU Y LA ANTESALA AL CONFLICTO}

El problema de los cementerios en Chile marcaría un antes y un después, cuyas rupturas al menos a nivel local, complicaron la posibilidad de una separación más armoniosa entre la Iglesia y el Estado en materia mortuoria. La Iglesia de Concepción no estaba preparada para enfrentar

${ }^{23}$ Carta Pastoral, Arzobispo Rafael Valentín Valdivieso y los infraescritos obispos José Hipólito Salas de Concepción, Juan Francisco de Paula Taforó de La Serena y José Manuel de Ancud. 7 de noviembre de 1874, Imprenta Nacimiento, Santiago, p. 6. Archivo Sala Chile, Universidad de Concepción.

24 Peralta 2007: 131-134. 
el desenlace mediático que implicaría el deceso de Manuel Zañartu, menos, bajo las condiciones y recriminaciones emanadas entre el conservadurismo y el liberalismo durante los últimos veinte años del siglo XIX. Los álgidos acontecimientos que derivaron el interés eclesiástico por conservar los cementerios religiosos en todo Chile, quedan sintetizados en forma certera por Ricardo Krebs. Al respecto, el autor explica:

Los católicos se sintieron heridos en sus sentimientos más íntimos y se consideraron perseguidos por el «liberalismo usurpador i tiránico» y «el despotismo más atroz» [...] La ley del 4 de agosto de 1883 que dio origen a los cementerios laicos fue interpretada como señal de que el liberalismo ateo había declarado una verdadera guerra al catolicismo, guerra que, aparentemente, se libraba contra los muertos, pero que, de hecho, iba dirigida contra los vivos y que obedecía al propósito de exterminar el catolicismo en sus raíces. ${ }^{25}$

A mediados de 1870 la salud del coronel Zañartu se vio afectada por el desgaste de una vida entregada al Ejército y la lucha independentista, debiendo suspender todas sus actividades públicas y sociales en Concepción. En la Sociedad de Beneficencia los documentos son escasos, y producto de los problemas de conservación existentes en Concepción, buena parte de los legajos referidos a Manuel Zañartu se encuentran extraviados, o bien, en su momento, pudieron ser ocultados para aquietar los ánimos en el polarizado ambiente social de la provincia.

Manuel Zañartu Opazo, un hombre que no se guiaba más que por su conciencia, decidió permanecer siempre al lado de la mujer que desde un principio fue el amor de su vida. No le importaron los constantes esfuerzos que se realizaron para persuadirlo a pasar sus últimos días junto a su esposa legítima, y así, poder recibir el perdón de sus pecados más la consecuente extremaunción. Zañartu persistió en su negativa hasta la muerte, incluso ante los esfuerzos personales del obispo Salas ${ }^{26}$, quién independiente de la distancia en torno a los ideales del coronel radical y masón, se preocupó por el desenlace fatal de este, encargando la continua asistencia espiritual a las Hermanas de la Caridad, a los miembros de la curía de Concepción, y los amigos personales de Zañartu. A juicio del obispo Salas, a un líder tan respetado como Manuel Zañartu Opazo no se le podía dejar desamparado, aún cuando el coronel no aceptase las sugerencias espirituales emanadas de la Iglesia local. José $\mathrm{H}$. Salas en su defensa a la causa católica, señaló lo siguiente:

Diferentes sacerdotes, animados de celo cristiano, pudieron acercarse al lecho del enfermo, le hablaron con la verdad que el caso exijia, le espusieron el estado de la enfermedad i la necesidad de prepararse para morir como católico, separándose de la casa de esa mujer. En este mismo propósito trabajaron las hermanas de la caridad, que fueron a visitarlo, i algunas otras personas [...] Pero todo fué inútil. El Coronel Zañartu no podia sufrir ni tolerar que se le hablase de separación del objeto de su liviana pasión: "pierde el tino» cuando este punto se le indica, me decía una noche en casa el Señor don Anibal Pinto, amigo del Coronel [...] A pesar de esta obstinación no se omitió por parte de los ministros de la iglesia medio alguno para alcanzar el resultado de una conversion sincera i de una muerte feliz en aquel infortunado enfermo. ${ }^{27}$

El requerimiento de la Iglesia fue desconocido por parte de Zañartu, su interés en permanecer y fallecer en casa de su amante era una convicción personal. Finalmente, el 5 de octubre de 1871 acontece el deceso, pero luego de su muerte se abriría una nueva oportunidad para quienes no contaban con la aprobación del catolicismo ante la inhumación de sus restos en Concepción, aun cuando estos fuesen propietarios de su tumba.

Tras la muerte de Zañartu, el obispo Salas en su calidad de párroco de Concepción, negó los pases de sepultación, pues consideraba que se corrompía el campo santo al sepultar un cadáver que no había fallecido conforme a la reglamentación del Derecho Canónico, ni mucho menos aceptado la extremaunción. Las leyes canónicas impedían que las personas fallecidas fuera de la bendición eclesiástica tengan la posibilidad de sepultarse en los cementerios de carácter parroquial, vale decir, en lo sagrado; tras negar la sepultación, Salas se dirige a Santiago de Chile aquejado por sus propios problemas de salud. Ante la negativa del obispo, el intendente Manselli, amigo personal y hermano masón en la logia que participaba con Zañartu en vida, ordenó romper los candados del cementerio de Concepción y proceder a la inhumación del cuerpo del coronel, el cual según se detectaba en la prensa, ya hedía, transformando la situación no tan solo en un problema espiritual sino de salubridad.

Fue en medio de los ritos masónicos y solemnes discursos que el coronel fue despedido, con una multitudinaria participación de los habitantes de Concepción, pues el revuelo que causó la determinación del obispo generó una animadversión profunda entre los habitantes de Concepción y la propia Iglesia, lo cual será analizado más adelante. La Revista del Sur fue uno de los principales medios en indicar el desenlace de las exequias del coronel. En su edición del 7 de octubre de 1871, publicó los detalles del traslado de los restos al cementerio de Concepción. Al respecto, la revista señaló:

Ayer a las tres de la tarde fue conducido el feretro al cementerio, acompañado de un numeroso concurso de personas de todas las clases y edades. Acompañado tambien de el batallon cívico del cual era comandante, para hacerle en el cementerio los honores de ordenanza. El carro, por haberse empleado los caballos, fue tirado por la jente del pueblo hasta el panteón [...] después de depositar el cadáver en la tumba, uno de los capitantes del batallon, don Herminio González, pronunció un discurso y leyó una parte de la hoja de servicio. En seguida tomó la palabra don Gregorio Pinochet teniente del mismo cuerpo, con la cual terminó la ceremonia. ${ }^{28}$

Los honores públicos que destacó la prensa obedecen demás, a que Zañartu era el último soldado de la Independencia que aún vivía en Concepción, esta característica en un país que forjaba su nacionalidad despertó profundos apegos a la figura histórica de Zañartu. En ello radica principalmente el impacto social que tuvo su deceso entre los habitantes de Concepción, el cual trastocó y convocó a buena parte de los representantes de las

\footnotetext{
25 Krebs 1981: 33.

26 Campos 1988: 50-65.
}

\footnotetext{
27 Salas 1872: 10.

28 "La Revista del Sur», Concepción, 7 de octubre de 1871.
} 
elites, los sectores medios y populares. Para recabar más antecedentes respecto de las manifestaciones populares en torno a las exequias de Zañartu, el periódico La Democracia del día 11 de octubre del mismo año, detalló los sucesos eventualmente, con una cuota de exageración en el número de asistentes. Al respecto, el periódico publicó lo siguiente:

Más de tres mil personas formaban el séquito fúnebre, entre hombres distinguidos, artesanos i hasta mujeres (sexo que no asiste nunca a esta especie de manifestaciones) de todas clases.

Los artesanos tuvieron feliz idea de querer sacar los caballos del carro que debía conducir los restos queridos del Sr. Zañartu, pero esta idea fracasó ante la voluntad del secretario Otárola i la órden del comandante de la policía Sr. Echeverria.

Sin embargo, los caballos a despecho de todos los que se oponian a que se sacasen, se obstinaron en no salir de la esquina de la administracion de correos i entonces los artesanos aprovecharon este incidente para apoderarse de ellos i llevar a su querido jefe tirado por sus propios brazos, hasta el mismo cementerio; ¡Honor de esos artesanos; ellos han sabido cumplir con su deber! [...] Los obreros de nuestro pueblo nos merecen pues hoi, un voto de aprobación, un algo mas que pueda compensar, como es justo, un acto puramente voluntario en que no ha influido el poder, sino la conciencia; en que no ha imperado el oro, sino el deber de ciudadano honrado, la satisfaccion de tributar al hombre ilustre, al viejo soldado, los últimos servicios, las últimas pruebas de verdadero i respetuoso aprecio. ${ }^{29}$

Respecto de esta publicación existen varios aspectos que destacar, el primero de ellos, obedece a la participación de mujeres en los actos públicos de militares. Tradicionalmente a estos acontecimientos concurrían mayoritariamente los hombres, por tratarse de una actividad en la cual las mujeres en su condición de subordinación, no podían tener participación pública, vale decir, no eran ciudadanas. En otro aspecto, el impacto de la figura de Zañartu fue tal, que pese a desarrollarse una ceremonia de carácter militar, los sectores populares intervinieron en la procesión replicando una conducta que es propia de los funerales pertenecientes a este sector social, el trasladar los restos del difunto entre todo el núcleo más cercano. El protocolo tradicional había sido modificado por artesanos y obreros, pues en esta clase de funerales propia de la posición social de Zañartu, debería hacerse: «[...] gala de la ostentación en todo su desarrollo, involucró [el funeral] la idea de generar un impacto y recuerdo visual a través de la magnificencia del cortejo, del número de oradores o del tipo de tumba...». ${ }^{30} \mathrm{El}$ acto de trasladar el cuerpo tirado por los brazos de artesanos u obreros, implicaba además, la presencia de la Religiosidad Popular en medio de cortejos oficiales, acercamiento que solamente habría sido posible gracias a que Zañartu - y por cierto, buena parte de los políticos liberales de Concepción- habrían desarrollado relaciones de acercamiento al mundo popular penquista a mediados del siglo XIX. La Religiosidad Popular frente a ese respecto, tendría que ver con una expresión más bien alegórica y afectiva hacia el ícono en que se había constituido Manuel Zañartu. Adicionalmente, el mundo obrero más ilustrado, eventualmente adscrito a las primeras gestiones de

\footnotetext{
29 "La Democracia», Concepción, 11 de octubre de 1871.

30 León 1997: 142.
}

Lorenzo Arenas ${ }^{31}$ en la sociabilidad obrera, habría percibido una cierta cercanía con el pensamiento radical del militar fallecido. En otras palabras, «La secularización respecto de las tradiciones populares se modernizaba conforme al desarrollo de la modernidad, por tanto, en gradual medida, el proceso no sería indiferente a los sectores populares ${ }^{32}$, configurándose en un grupo social que adscribió un sentido crítico respecto de las disposiciones eclesiásticas en materia social.

La configuración de la muerte del otro, según Philippe Ariès: "La exalta, la dramatiza, pretende que sea impresionante y acaparadora [...] el otro cuyo lamento y recuerdo inspiran en los siglos XIX y XX el nuevo culto de las tumbas y los cementerios"..$^{33} \mathrm{El}$ funeral se constituyó en un acto representativo, en este sentido, del aprecio y admiración por el difunto, a quién se le despedía con el dramatismo propio explicado por el dolor que legítimamente ocasionaba el fallecimiento de una figura pública y consentida por los penquistas. Lo anterior, sumado a las características del cambio cultural del siglo XIX, las cuales en su proyección histórica habrían sido las responsables que el cementerio en cuestión, además de un lugar de reposo, se reconociese como un espacio destinado a la memoria por el descanso de quién ya no estaba en el mundo de los vivos.

El deceso del coronel habría sido uno de los primeros y más fuertes quiebres entre las facciones liberales y el conservadurismo. La política y la relación entre la Iglesia y el Estado no volverían a tener el mismo obre que antes. Respecto del campo santo, destinado para la muerte del católico, a raíz de los acontecimientos que se estaban suscitando por ser concebido como parte del espacio público, frente al tema de la muerte se «[...] abriría un espacio para los disidentes, sin contrariar el derecho canónico, y se abriría a futuro un nuevo espacio estatal plural... $\|^{34}$, con el propósito de reivindicar las necesidades ciudadanas de la disidencia, cuya necesidad religiosa no era bajo ningún aspecto suplida por el catolicismo envolvente de la sociedad finisecular del XIX, en cuyo caso, debía ser readecuada por los parámetros que demandaba la ciudadanía. El catolicismo se resistía ante las dictaminaciones y posibilidades de abrir el campo santo, a las sepultaciones de quienes no eran católicos. Las cosmovisiones presentes en la cultura católica del siglo XIX situaban al cementerio en un espacio sacro destinado a la muerte, lo cual según Marco León implicaba:

[...] un espacio sagrado de la muerte, cualquier intromisión de otro credo religioso o de algún indigno para la Iglesia en ese recinto, quebrantaba el carácter sacro que la autoridad eclesiástica, junto con la civil, habían reconocido al camposanto. ${ }^{35}$

La interpretación valórica fue la que en cierta medida, habría precipitado la resistencia eclesiástica ante las determinaciones del gobierno de lo que denominarán como Leyes Laicas. La transformación religiosa sería un proceso que, gradualmente, demarcado por la secularización, desde 1860 en adelante, estaba configurando el cambio cultural del Chile tradicional.

\footnotetext{
31 Pacheco 2003: 178-182.

32 Elgueta Reyes 2012: 87.

33 Ariès 2000: 53.

34 Serrano 2008: 236.

35 León 1997: 47.
} 
FIGURA 2

Tumba del coronel Manuel Zañartu Opazo ubicada en el cementerio de Concepción

La fotografía fue tomada en tres ángulos distintos. El mausoleo originalmente contaba con una columna griega en la parte superior. Actualmente se encuentra en reparaciones tras los daños ocasionados por el terremoto del 27 de febrero de

2010. (Fotografía tomada en marzo de 2013, colección del autor)
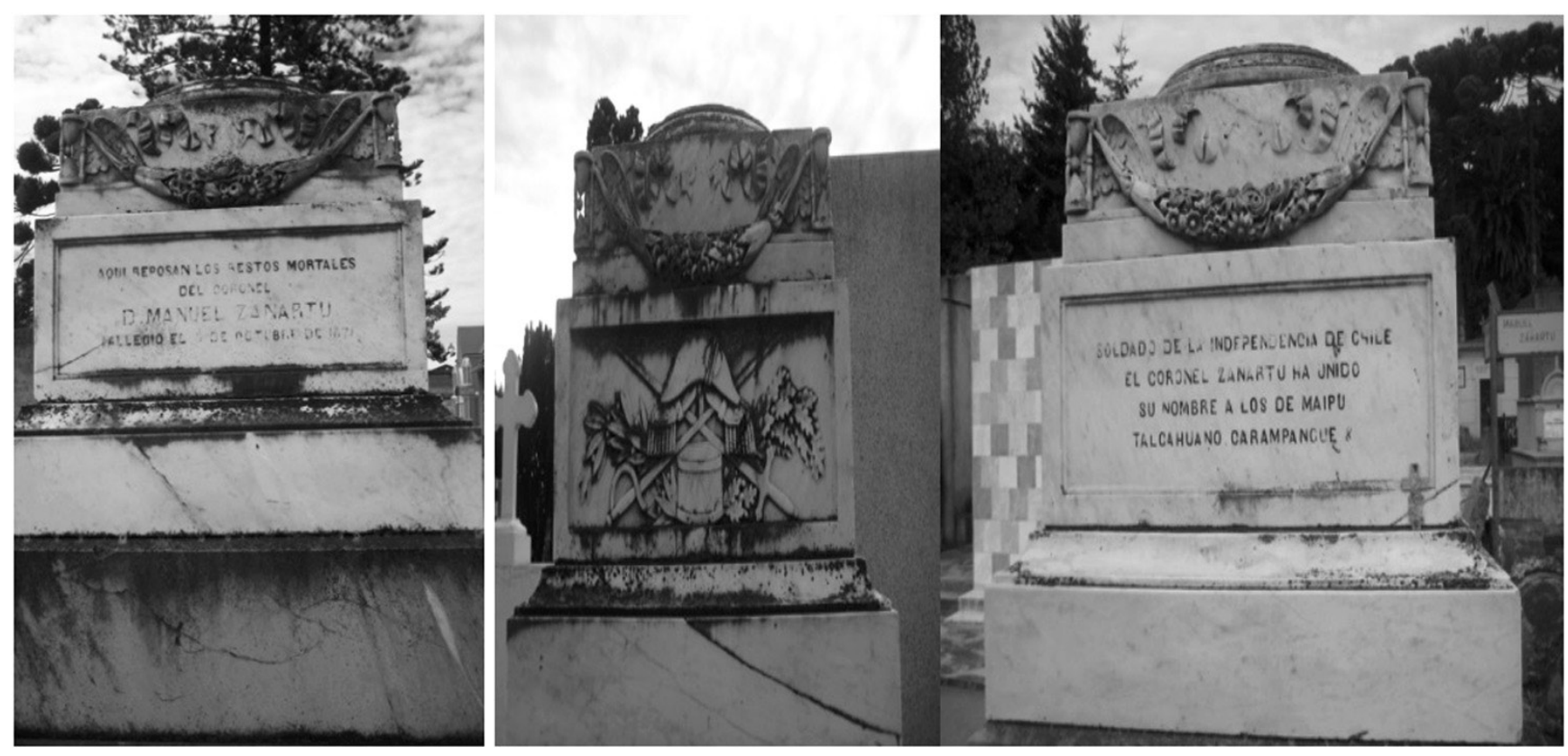

El obispo Salas, quién todavía permanecía en Santiago recuperándose de su delicado estado de salud, al enterarse de la determinación ejecutada por el intendente Manselli, elevó una nota de reclamo al Gobierno, sin embargo, este respondió que el cementerio de Concepción se encontraba secularizado, y bajo la administración de la Beneficencia de Concepción desde hacía bastante tiempo. La contrariedad de Salas quedaría manifestada en una de sus cartas dirigida a quién era por aquel tiempo, el ministro de culto del gobierno del presidente Errázuriz Zañartu. En la misiva, Salas expresa su molestia y defiende sus ideas, exponiendo sus razones de cómo le habría gustado que se desarrollaran los acontecimientos por parte del Gobierno y sus ministros. El día 26 de diciembre de 1871, el prelado de Concepción escribía:

[...] ¿Qué diré a U. de lo que se llama desenlace de la cuestión Zañartu [...]? En cuanto a mi que no me abaten las iniquidades de gobiernos i parlamentos i en cuanto a Ud. que deploro en mi alma que también sea victima de este combate contra el derecho i la verdad católica [...] si solo se hubiera limitado a establecer el derecho para todos de trabajar cementerios particulares, si se hubiera mandado a agregar alguna parte no bendita a los cementerios existentes para sepultar a los que no tienen sepultura eclesiástica, todo eso habria merecido la aprobación de todo los católicos sinceros. Pero mandar a profanar una parte del lugar bendito $\mathrm{i}$ consagrado por lo mismo al culto i esto sin contar para nada con la autoridad de la Iglesia i despues de ello secularizar completamente estos lugares sagrados hacer de ellos en adelante un potrero del estado para desterrar carnes muertas humanas eso es ir mui lejos, es llevar el liberalismo i la ansia de popularidad mas alla de sus limites... ${ }^{36}$

La profanación del territorio destinado a la sepultura de los fieles católicos, fue lo que generó mayor molestia al obispo José Hipólito Salas. Su determinación de negar la sepultación desembocó en un conflicto entre la ley eclesiástica y la secular. A su juicio, la administración del cementerio debería haber delimitado un sector especial, separado por rejas, en el cual disidentes y aquellos difuntos sin sepultación canónica pudiesen ser inhumados sin problemas, esto, a fin de evitar la profanación de lo que Salas denominaba como un campo santo. Pese a los esfuerzos del catolicismo por preservar el orden moral católico de lo público, los antecedentes seculares en la cultura estaban generando transformaciones en la muerte de los chilenos la cual pese al conflicto de Zañartu, se irá convirtiendo en un espacio de vital importancia para el Estado, por cuanto las corrientes culturales en parte, aportadas por la inmigración europea del siglo XIX, estaban considerando que: "las tumbas de los héroes y grandes hombres serían veneradas allí por el Estado». ${ }^{37}$ En el caso chileno, las costumbres republicanas con el ímpetu forjador de la nacionalidad chilena, serían las responsables de plantear el cementerio como un espacio para la memoria patria; ello explica que

36 El subrayado es nuestro. «Carta del Obispo José Hipólito Salas dirigida al Ministro de Culto Abdón Cifuentes», 26 de diciembre de 1871, volumen de correspondencias, s. f., Archivo del Arzobispado de Concepción.

37 Ariès 2000: 65. 
la tumba del coronel Manuel Zañartu fuese considerado un monumento ${ }^{38}$ a la causa militar y civil que en vida desarrolló el soldado conmovido por su patriotismo. El liberalismo y radicalismo de finales del siglo XIX, estaban comenzando a emplear las tumbas de personajes connotados para transformarlas en monumentos patrióticos a los próceres de la Patria.

Retomando la argumentación de Salas respecto de las exequias forzadas de Zañartu, como se aprecia en las palabras del prelado, al permitirse la sepultación de una persona sin la bendición sacerdotal, faltando por consiguiente a la voluntad de un párroco, el liberalismo como enemigo de la Iglesia se había extralimitado. A partir de la perspectiva de Salas, se había herido la susceptibilidad del clero y mancillado la moral católica. Posteriormente, en la misma carta, Salas se pregunta: «y en las franquicias que tienen los Intendentes para hacer impunemente toda clase de fechorias con respecto a las leyes de la Iglesia ¿quién les estorbará en sus escandalos?...». ${ }^{39}$ La irreverencia de Salas, suscitada por su enojo, no permitía ningún tipo de postergación para la injerencia eclesiástica, la cual en función de la moral católica del Estado de Chile, debía ser respetada.

Pese al llamado alegórico del obispo, y a toda la legislación canónica aún vigente en algunos cementerios de administración parroquial, se debe destacar que sí se estaba buscando esclarecer por parte de la Sociedad de Beneficencia de Concepción, el tema de los disidentes en el cementerio de la ciudad. Para la administración del campo santo, era necesario tener claridad respecto de quienes han fallecido sin la bendición católica, preocupación que estaba presente desde el año 1865, seis años antes del desenlace en torno a la problemática de los cementerios en Chile. Respecto de la preocupación por los disidentes, en los registros de la Sociedad de Beneficencia de Concepción es posible revisar una nota firmada por el ex Intendente Aníbal Pinto en la cual, se ordenaba el recuento de todos los cadáveres inhumados en el cementerio de Concepción en calidad de disidentes de posibilidad, vale decir, sepultados con cuestionamientos por parte de la autoridad católica:

La Intendencia necesita que $U$ le pase a la brevedad posible, una razon del número de disidentes de posibilidad que han sido sepultados en el respectivo cementerio desde su establecimiento hasta el 31 de diciembre del año próximo pasado, con reparacion de los parrocos de los adultos; así mismo necesita que la oficina de su cargo pase mensualmente esta misma razon dando principio desde el mes de enero del corriente año. ${ }^{40}$

Aun cuando la Junta de Beneficencia de Concepción era una entidad secular, trabajaba a la par con la Iglesia en asuntos que se vinculaban a la moral y la muerte. Ello explica la presencia de un párroco y una capilla disponibles en el

38 Al respecto, véase la Fig. 2.

39 "Carta del Obispo José Hipólito Salas dirigida al Ministro de Culto Abdón Cifuentes», 26 de diciembre de 1871, volumen de correspondencias, s. f., Archivo del Arzobispado de Concepción.

40 «Oficio de la Intendencia de Concepción, remitido por Aníbal Pinto con el objetivo de esclarecer los totales de posibles disidentes que hayan sido sepultados en el Cementerio de Concepción», 15 de mayo de 1865, vol. año 1865, Archivo de la Sociedad de Beneficencia de Concepción. cementerio de Concepción, cuyo propósito era atender los decesos de personas principalmente asociadas a la elite.

Salas consideraba este agravio como una flagelación grave a los principios del catolicismo. Este lazo aparente que se apreciaba entre los poderes gubernamentales y el religioso, habría quedado deshecho tras una tensión propia de la coyuntura política de Concepción y el resto de Chile. Salas no escatimaba esfuerzos en manifestar su malestar en cuanta tribuna le hubiese sido posible, a Crecente Errázuriz le escribe en el mes de diciembre de 1871 lo siguiente:

Yo no me espanto ni me abato por censuras de Camaras o de gobiernos cuando defiendo los derechos de la Iglesia [...] En esta cuestion Zañartu la Iglesia i la moral son las flajeladas. El triunfo es de los malos i con el no ganara amigos la administración de D. Federico, a pesar de sus decretos sobre cementerios [...] deje $U$. celebrar la victoria sobre todo aqui, de los que combatimos para hacer triunfar la candidatura de su hermano [...] En pocos días se erijira con gran fiesta i con discursos el mausoleo de Zañartu que tiene un anjel en su coronación [...] El Sr. [Abdón] Cifuentes es un perla, pero dudo que se mantenga en su puesto. Su alma es pura i su corazón mui bueno. ${ }^{41}$

Cabe destacar las referencias despectivas que Salas manifiesta respecto de los rojos-montvaristas, antecedente que da cuenta de la preocupación por el creciente poder e influencia del pensamiento disidente en Chile y Concepción. El prelado consideraba que el liberalismo nocivo más allá de afectar a la fe católica, disminuía la influencia que la Iglesia tenía. El régimen portaliano le había otorgado a la Iglesia católica ser la institución que garantizaría el orden moral en la República ${ }^{42}$, por lo tanto, no es coincidencia que el discurso de Salas en contra de los liberales penquistas y nacionales, centrara su enfoque en el desorden y la irrelijiosidad que despertaban los gobiernos liberales.

Pero más allá de toda la moralidad que representan los intereses del obispo, ¿̇la reacción del prelado y su curía habría sido la misma si el fallecido hubiese sido un sujeto (a) menos conocido que el coronel Manuel Zañartu? Aparentemente, y por razones obvias, las figuras promitentes de la sociedad son las que más influencia generan en el medio. Los sujetos populares quedan por lo general, relegados a un segundo plano, dado a que sus causas no poseían mayores relevancias para la visión elitista existente en el período analizado.

\section{EL IMPACTO MEDIÁTICO DEL CONFLICTO PARA EL OBISPADO DE CONCEPCIÓN}

El deceso de Manuel Zañartu marcó el inicio de una polémica que, desde 1871 en adelante, generó un profundo debate tanto en la prensa liberal como en la conservadora. El principal espacio de dominación católica que era el cementerio municipal de Concepción se secularizaba, o bien, separaba desde el plano cultural, pues administrativamente no dependía del obispado. En virtud de la desavenencia, el debate y defensa de ideas hacia una u otra postura por

41 «Carta del Obispo José Hipólito Salas dirigida a Crecente Errázuriz», 29 de diciembre de 1871, volumen de correspondencias, s. f., Archivo del Arzobispado de Concepción.

42 Villalobos 2012: 260-263. 
medio de la prensa, logró incrementar las animosidades negativas entre liberales y conservadores. Concepción ya había sido partícipe de un conflicto civil en 1851, condición que mantenía a buena parte de los penquistas de mediados del siglo XIX con rencores a flor de piel. Podría plantearse a modo de hipótesis que, la sensibilidad de los liberales desde el fatal desenlace de los sucesos de 1851 contra el gobierno central de Santiago, habría quedado con una importante animadversión, y en consecuencia, ante cada oportunidad que se pudiesen manifestar en contra del conservadurismo centralizado, bien podría haber coadyuvado a una postura más intolerante de parte de liberales hacia los conservadores, y viceversa.

Hacia el mes de mayo de 1872, un segundo acontecimiento hirió las sensibilidades del obispado de Concepción. En la localidad de Tomé se había irrumpido el cementerio parroquial del lugar por parte de un funcionario de gobierno, situación que evidentemente no fue bien recibida por la Iglesia. A diferencia del cementerio penquista, el de Tomé estaba íntegramente administrado por su parroquia, por tanto, los decretos dispuestos por el gobierno bien podrían haberse aplicado con otro criterio para la localidad. Dicha irrupción -que también pasará a denominarse, en atención y consecuencia a los sucesos, como un despojo por las autoridades eclesiásticas - trajo aparejada la inmediata crítica del periódico La Libertad Católica, portavoz de la Iglesia local que vociferó su mensaje con una enérgica publicación respecto de la situación acontecida. Al respecto, en el artículo se expuso:

Triste es decirlo; pero es la verdad. El señor Ministro del Interior aprueba el atropello cometido por el gobernador de Tomé, que descerrajó las puertas del Cementerio de aquella Parroquia, i se hizo dueño del mismo; i aprueba que lo hecho sin restriccion de ningun jénero. Examinemos con la calma que es posible en estos casos las razones del gobernador i el ministro [...] Más arriba de las disculpas del funcionario atropellador, mas alto que el laicismo ministerial se perciben dos principios de derecho que han guiado al primero en sus violencias i que han obligado al segundo a dar la bendicion a los hechos consumados.

$1 .^{\circ}$ quien fué dueño del terreno donde se estableció un Cementerio es tambien el dueño del cementerio; $2 .^{\circ}$ cuando el fisco o una Municipalidad se creen señores de una propiedad pueden sin mas auto ni traslado irse sobre la cosa disputada i hacer uso para ello de la fuerza pública». ${ }^{43}$

Este suceso constituyó un golpe trascendente a la influencia política de la Iglesia del siglo XIX. Pese a que las disposiciones del gobierno aprobaban que los cementerios de administración municipal -como también, en aquellos administrados por las juntas de beneficencia- existiese un patio para los disidentes, en los cementerios parroquiales la condición resultó ser poco clara, o bien, contradictoria para la Iglesia considerando lo estipulado por el Derecho Canónico en materias de defunción y administración del campo santo.

El fundamento defendido por la Iglesia, obedecía a que fue objeto de una expropiación de su cementerio parroquial en Tomé. Se enmarcó en el segundo acontecimiento que dio

\footnotetext{
43 «La Libertad Católica», Concepción, 25 de mayo de 1872.
}

inicio al despojo de los cementerios; este nuevo golpe implicó la definitiva caída de la Iglesia en la esfera pública, pues si ya por la cuestión del sacristán ${ }^{44}$ el escenario católico fue alterado en sus influencias del plano legal, estos despojos y los acontecimientos suscitados tras el deceso de Zañartu fueron los que terminaron por sepultar la presencia del Dr. José Hipólito Salas en la esfera penquista como referente moral.

En un sentido particular con el tema de los cementerios, José Clemente Fabres en su crítica respecto de las medidas adoptadas por el Intendente Manselli, indicó que la distribución de los espacios al interior de los campos santos era materia exclusiva de la autoridad eclesiástica. Al respecto Fabres señaló:

El mandato de separar en cada cementerio una parte para la sepultación de los indignos de sepultarse en sagrado, esa materia sola de competencia de la Autoridad Eclesiástica; porque siendo los cementerios cosa sagradas al culto divino, se rigen por el Derecho Canónico, según disposiciones expresa de la ley y de la Constitución de la República. ${ }^{45}$

La enigmática figura de Salas tampoco se quedaba ausente de las consecuencias legales relacionadas con el despojos de cementerios. El obispo de Concepción en su constante deambular de opiniones se mantenía siempre en contacto con el arzobispo de Santiago, ambos compartieron las visiones respecto del agravio al cual la Iglesia fue objeto. El prelado de la diócesis de Concepción ni en las festividades de año nuevo lograba desentenderse temporalmente del problema, pues el 1 de Enero de 1872 escribe al arzobispo Dr. Rafael Valentín Valdivieso señalando:

Su mui grata del 26 pasado llego mui a tiempo. Deseaba muchísimo conocer todo su pensamiento en orden a esos decretos del gobierno sobre cementerios. Nuestras ideas estan en el mas perfecto acuerdo [...] El Idependiente [periódico de circulación nacional y local] esta demasiado gobiernista i sin reservas canta sus alabanzas al gobierno por sus decretos sobre cementerios [...] Tengo para mi que si el Gobierno hubiera publicado a tiempo sus tan pensados decretos o si hubiera pronunciado siquiera una palabra de improbación de la conducta de este Intendente no habría habido interpelación. Creo mas i es que si todos los ministros hubieran sido tan leales $\mathrm{i}$ consecuentes como D. Abdon, los conciliadores, rojos i montvaristas no habrían triunfado [...] para alcanzar esa victoria. Con ella no ganara hombres el gobierno; pero si perdera como ya ha perdido amigos [...] Halaga sin duda tener votos de confianza a costa de la Iglesia i sus Pastores; pero yo dudo que esas amistades sean durables [...] Yo noto en los decretos sobre cementerios $=1^{\circ}$ una invasión a la propiedad de la Iglesia por el hecho de asignar sin su consentimiento una parte de lo que le pertenece a otro objeto $=2^{\circ}$ La profanación de este local por el solo querer del gobierno. $3^{\circ}$ La única puerta para entrar a ambos cementerios. Esta precaución es hija de la cobardía o del miedo a la gente de malas ideas o no mas que una vejación mas al derecho de la Iglesia. $4^{\circ}$ Estralimitación de facultades en la secularización de los cementerios que en adelante se construyesen también para

44 Moscoso 2006: 131-136.

45 Fabres, C. Obras completas Tomo IV, citadas por Fernández 1989: 58. 
católicos por el fisco, mientras las leyes vijentes no se derogen aun civilmente los cementerios pertenecen a la Iglesia. $5^{\circ}$ Derogación de la lei canonica por un decreto de gobierno. $6^{\circ}$ La iniquidad de cementerios profanos en un país esclusivamente católico...». ${ }^{46}$

Además de las observaciones dispuestas a los decretos que antecedieron la Ley de Inhumación de Cadáveres (1883), Salas consideraba que detrás de todos los despojos, se levantaba una animadversión en contra de la presencia católica. Frente a esta coyuntura de críticas entre ambos sectores, el obispo Salas, presumiblemente por sugerencias emanadas de parte del arzobispo Valdivieso, comenzó a considerar la idea de escribir un libro para defender y esclarecer los argumentos y acciones tomadas por él mismo, en virtud de los lineamientos ideológicos y políticos convenientes a la Iglesia católica. Respecto de este punto, Salas indicaba al arzobispo que muchas de las consultas que se desarrollaron para publicar los decretos de gobierno respecto de los cementerios habrían sido falsas, y por tanto, las afirmaciones del diario El Independiente habrían sido una manipulación de Gobierno para validar los decretos que oficializaron el Despojo de los Cementerios. Al respecto, el prelado penquista afirmaba:

[...] la reacción del Independiente [Periódico favorable al gobierno] que quema incienso $\mathrm{i}$ aplaude con ambas manos los decretos antedichos se escusa con la razon de que estos han sido previamente consultados $\mathrm{i}$ aprovados por las personas que rodean $\mathrm{V}[. .$.$] yo no$ creo tales aprobaciones; pero me parece fuera de duda que se trabaje por hacerlo creer [...] Y esto perjudica sobremanera a la causa católica [...] estoi dispuesto a colocarme en el terreno que $\mathrm{V}$. quiera en la defensa de la Iglesia. Pienso escribir pronto i sin miedo con la gracia de Dios. ${ }^{47}$

Pese a las tesis de apoyo lideradas por el obispo Salas, los aires de modernidad habrían revocado la tradicional facultad de solicitar autorización al párroco para sepultar un cadáver. El problema en este caso, se orientó a un tema de salubridad y de la propiedad privada, además del impacto social que el deceso de Zañartu habría ocasionado. ${ }^{48}$ En una primera instancia, se podría establecer que el problema en sí mismo, obedecía a una cuestión de carácter política por sobre otra forma de percibir el conflicto, como una simple lucha de poderes sin mayores trascendencias que una escueta ley laica; sin embargo, la problemática es mucho más profunda que una dialéctica de poderes.

La prensa conservadora tenía su principal voz anunciadora en Concepción gracias al diario La Libertad Católica, publicación organizada por el obispo Salas con el propósito de crear un medio de divulgación para el Partido Conservador en el plano local. Respecto de sus antecedentes y proyección en el tiempo, Fernando Casanueva señala: «[...] es un periódico bisemanal fundado el 22 de noviembre de 1871 . Se recibió en la Biblioteca Nacional hasta el N 3.731 de 14 de agosto de $1892 » .{ }^{49}$ Sus primeras publicaciones se iniciaron en

46 «Carta del Obispo José Hipólito Salas dirigida al Arzobispo de Santiago Dr. Rafael Valentín Valdivieso», 1 de enero de 1872, volumen de Correspondencias, Archivo del Arzobispado de Concepción.

47 Ídem.

48 Palacios Roa 2006: 30-34.

49 Casanueva 2002: 236.
1871, período en el cual, no podría constituirse en un mejor escenario para defender a la institucionalidad eclesiástica de los ataques y ofensas - que a juicio de los conservadores de Concepción, en conjunto con el propio obispo Salasefectuaban los sectores más radicales y liberales en general, tanto desde el medio local como nacional.

La relación existente entre el conservadurismo y el obispo Salas respecto de la creación de un periódico opositor a las voces liberales, no ha sido abordada por quienes se han abocado al estudio de la historia de la Iglesia católica en Chile. Existe sin embargo, la biografía del obispo Salas escrita por Fidel Araneda Bravo, quién es el único autor abocado a entregar antecedentes concretos de la participación del obispo en la creación de un periódico portavoz del conservadurismo local. Al respecto, Araneda indica lo siguiente: «[...] Salas invitó a su propia casa a un grupo de conservadores para fundar un periódico [...] un Partido sin diario o periódico que le sirva de arma es un músico sin instrumentos y un soldado sin armas [...]» (Araneda citando palabras del Obispo Salas)..$^{50} \mathrm{~A}$ partir del planteamiento de Araneda, más el contenido revisado en el presente artículo, se establece que Salas pese a indicar en más de una carta que no estaba interesado en cuestiones políticas, indirectamente, se convierte en un estratega político. Es por medio de sus postulados de prensa frente a las circunstancias consideradas para él y la Iglesia como adversas, en que sale a relucir toda su cosmovisión de la salvación, acompañada de los importantes designios que Dios tendría para la ciudad y la nación chilena.

Retomando nuevamente la cuestión de los cementerios, es posible advertir con claridad los propósitos defensivos ante la causa de la moral y la Iglesia en una publicación del mes de marzo de 1872. El artículo de La Libertad Católica tiene como objetivo iniciar las explicaciones de los distintos episodios que se adscribieron al deceso de Zañartu, que a juicio de la Iglesia, transgredieron los valores de la moral cristiana y la reglamentación dispuesta por el Derecho Canónico. En relación al tema, el obispo de Concepción indicó:

Mi causa era i es buena, excelente, santa; porque es la causa de la Iglesia i de la moral. Sin mucho trabajo podía haber opuesto antes, como lo haré ahora, la razon, el derecho i la lei a las huecas declaraciones i a las injurias soeces de los que en mí aborrecen a la Iglesia. Pero yo debía callar i he callado... ${ }^{51}$

El recurso empleado por Salas apuntaba a despertar los fervores que el catolicismo generaba en sus adeptos. Paralelamente, el prelado se inmiscuye en discusiones que permiten revelar la percepción sociocultural del período, que por ende, revelan los rasgos culturales y por cierto, contrastables a la realidad histórica de la religiosidad popular en Concepción y Chile:

En los tiempos que corren i con los rudos golpes que a la virtud se dan, i con los honores que al cinismo i a la inmoralidad se decretan, este escrito es indispensable, necesario, sagrado deber para mi. No estado mi defensa, como la de la Iglesia i de la familia católica la que emprendo esta vez. Lastimados en nuestros mas caros intereses, no se nos puede negar el derecho de

\footnotetext{
50 Araneda 1963: 101.

51 «La Libertad Católica», Concepción, 13 de marzo de 1872.
} 
protestar siquiera contra las grandes iniquiedades, i si mas voz no hubiera que la mia para cumplir este deber, ella se alzaría con toda la enerjia i libertad de mis convicciones católicas. ${ }^{52}$

Estos rasgos culturales que se aprecian en la alegoría de la moral y los golpes a la virtud, se relacionan directamente con la crisis política que el conservadurismo estaba enfrentando. Salas comprende que los ataques a su persona y la Iglesia - a raíz de negar la sepultación de una carne muerta, como lo dispone en una de sus cartas citadasobedece a un problema que en los alcances religiosos, se asocia a la salvación de las almas pías; este era el fin último que la Iglesia buscaba en sus propósitos; al corromperse un cementerio con un cuerpo muerto -espiritual, y sin la bendición sacerdotal- contaminaba y podía afectar a la salvación de las almas sepultadas bajo la regularidad católica. Por tanto, la defensa de los ataques liberales debían fundamentarse en un plano religioso, citando la doctrina bíblica y aludiendo siempre al sentido espiritual del público receptor del discurso: el ciudadano católico de un Estado católico. ${ }^{53}$ Más allá de la dimensión moral de problema junto a las evidentes consecuencias en lo político, el conflicto se asociaba paulatinamente al concepto de la propiedad privada.

El coronel Zañartu era propietario de su sepultura, y al ser poseedor de un bien privado, resultaba irrisorio que de parte del obispado de Concepción se le negasen las exequias a un difunto que en vida había adquirido la propiedad. Lo anterior resultaba todavía más evidente, porque el cementerio era administrado por la Sociedad de Beneficencia, institución que no tenía ninguna vinculación administrativa con la Iglesia local, más allá de contratarse un sacerdote para oficiar los responsos del cementerio, entre otras prestaciones de servicio de los conventos para asistir enfermos en los hospitales y el Hospicio.

José Hipólito Salas se caracterizó por ser el obispo que pastoreaba las almas feligresas de Concepción, y al mismo tiempo, era el prelado que resguardaba la política conservadora y local. Desde dicha perspectiva, toda defensa de los intereses eclesiásticos más la correspondiente lucha por ese espacio público en disputa -en este caso, el cementerio de Concepción - se estaba constituyendo en una secularización desde la perspectiva cultural. La vorágine secularizadora se caracterizó en dicho sentido, por el relegamiento de la Iglesia en lo público, como de igual modo, de la forma tradicional de pensar, pues la modernización religiosa -o también conocida como la estampida de los fieles $^{54}$, entre otras formas de percibir la distancia gradual de la Iglesia en lo público- se materializó por la exclusión que la misma Iglesia provocaba hacia las tendencias de pensamientos confesionales distintos, los no católicos. Lo antes señalado explica la fuerte injerencia del sacerdocio local en el Partido Conservador, en tanto se comprendía que la religión era un elemento de orden y control moral en la población, característica que se heredaba del pasado colonial en Chile e Hispanoamérica. ${ }^{55}$

\footnotetext{
52 Ídem.

53 Serrano 2008: 175-216.

54 Prado 2007: 9-12.

55 León 2005: 33-38.
}

La cultura penquista se desarrollaba conforme a los aciertos y desaciertos de la Iglesia más los vaivenes que se desplegaban en la política chilena del siglo XIX, un período de tiempo cargado por el imaginario de las guerras tanto externas como civiles. Por el contrario, la piedad católica representada en la figura del enigmático José Hipólito Salas, escondía dentro de sí misma un interés que trascendía a lo espiritual, redefiniéndose el rol del obispo de Concepción para convertirse en un estratega político que maquinó toda clase de situaciones para poner tropiezos a la administración del presidente Federico Errázuriz Zañartu, mandatario que el mismo Salas había apoyado al momento de su elección.

Los temores del obispo Salas y sus preocupaciones respecto de la situación política chilena fueron evidentes, pues se trataba de una época en la cual «[...] la Iglesia se sentía claramente amenazada porque las aspiraciones del Gobierno liberal habían tensionado sobremanera, por un lado a la jerarquía católica, y por el otro a todos aquellos elementos políticos que defendían la potestad del Estado...». ${ }^{56}$ El Estado, a su vez, se robustecía restándole injerencia a la Iglesia en aquellos planos en los cuales el catolicismo tuvo una influencia institucionalizada. La muerte fue, según lo analizado en el presente artículo, una de las transformaciones culturales que se restó a la Iglesia en cuanto a su influencia más directa.

Finalmente, cabe destacar que la defensa de la Iglesia en materia de los cementerios se encontraba situada en otra vertiente de intereses que complementan la motivación de figuración pública. El Estado reclama secularizar un espacio que no fue propio de la Iglesia, pues era el mismo Estado el responsable de entregar los cementerios públicos a la administración eclesiástica, la que a su vez, dictaminó una desavenencia al recriminar la actitud eclesiástica ante el deceso de Zañartu. En medio del debate álgido, la Revista del Sur en su publicación del día 2 de noviembre de 1871 entrega la explicación en torno a la protesta desarrollada por el obispo Salas. En relación a la materia, se publicó lo siguiente:

Los cementerios públicos de Chile están confiados, en la jeneralidad de los casos a la autoridad eclesiástica. El poder civil ha metido la mano en la administración de sus fondos y en todo lo que puede llamarse administración material; pero en lo que tienen de relijioso, como es la consagracion y los requisitos que deben observarse para la sepultación de los cadáveres, nadie sino la autoridad eclesiástica puede intervenir. Asi los disponen leyes civiles vijentes como aquélla de partidas que cita el Iltmo. señor Salas en su nota. ${ }^{57}$

Teniendo en cuenta el antecedente previo, el Estado chileno durante todo el siglo XIX había delegado y compartido buena parte de sus funciones sociales con la Iglesia. Dicha disposición generó una suerte de dependencia e instrumentalización de lo religioso con fines políticos y estatales. El Estado chileno se ha beneficiado de la Iglesia para afrontar los problemas sociales asociados a la pobreza, lo cual se había concretado a partir de las sociedades de beneficencia en las cuales, se trabajó en la asistencia

\footnotetext{
56 Salinas Araneda 2009: t. III, 284.

«La Revista del Sur», Concepción, 2 de noviembre de 1871.
} 
pública valiéndose en parte de algún servicio otorgado por una u otra orden religiosa católica; a modo de ejemplo, en Concepción podemos encontrar hacia 1870 la presencia de las Hermanas de la Caridad, tanto en la visitación de enfermos como también en el hospicio de la ciudad.

El problema que se suscitaba respecto de la muerte impenitente estaba reglamentado por las leyes canónicas, las cuales impedían la sepultación de un difunto en lo sagrado ante circunstancias que, al momento previo de su deceso, no hubiese recibido ni expiado sus culpas mediante la confesión u otra disposición que permitiese cambiar la condición de impenitencia. En el artículo ya citado de La Revista del Sur se trató este asunto, entregándose antecedentes que son relevantes para complementar más la mirada hacia la muerte de Zañartu. Al respecto, la revista publicó:

Ahora bien, si se recuerda que las leyes eclesiásticas castigan con penas severísimas al párroco que permita el entierro en sagrado del cadáver de un individuo que no cumple con los requisitos canónicos, se verá que en sus reclamos y en sus resistencias no obedecen a otro espíritu que el deseo de cumplir con un deber sagrado. ${ }^{58}$

En el artículo, más allá de criticar a una u otra postura, se analiza el problema desde las disposiciones legales que se ven inmiscuidas en el conflicto. Si tan solo se pudiesen revisar los antecedentes exclusivamente publicados por la prensa, bien podría concluirse a este respecto que los reclamos de Salas irían más bien en el sentido de la legalidad, sin embargo, al revisar el epistolario personal del obispo, es posible visualizar un interés netamente político, cargado de odiosidad y descrédito hacia los liberales contrarios. Desde otra perspectiva, el liberalismo responderá con críticas y más descrédito, intentando sacar partido de la impopularidad de Salas obtenida gracias a su intervención en el asunto de Zañartu; ante tales reminiscencias negativas entre el sector liberal y parte del conservadurismo representado en el obispo de Concepción, y en medio de un proceso de secularización que pretendía posicionar el bienestar ciudadano, la figura de la Iglesia en lo público se vio envuelta en una imagen de retraso en materias sociales.

Para afrontar el problema de los cementerios considerados católicos, desde la perspectiva de La Revista del Sur, se sugería la posibilidad de crear cementerios neutrales como una posible medida para solucionar futuras controversias entre la Iglesia y el Estado en materia religiosa y legal. Los cementerios neutrales habrían permitido inhumar cadáveres de religiones, credos, u otras perspectivas distantes del catolicismo, constituyéndose además, en espacios neutrales que permitirían el responso a los habitantes que fallecían en circunstancias similares a las del coronel Zañartu. La publicación respecto de este tema, propuso lo siguiente:

Sucede, sin embargo, que muchas veces, sea por ignorancia, sea por espíritu de hostilidad, sea tambien por que comprenden que no es posible privar de sepultura el cadáver de nadie [...] Por cualquiera de estas causas el conflicto surje y su decenlase como lo hemos dicho [...] Es fuerza, pues buscar el medio de removerlo, y el único que nos ocurre y que puede satisfacer la exijencia lejítimas de todos es la creación de cementerios

\footnotetext{
58 Ídem.
}

neutrales en que hallarian sepultura los cadaveres de personas que no hubieran profesado relijion alguna, o que, siendo católicos, hubieran sido impenitentes. ${ }^{59}$

Si bien en algún momento se pensó remover el cadáver de Zañartu, finalmente la administración del cementerio de Concepción optó por dividir el campo santo, erigiéndose una reja que separaba el sector en dónde se encontraban las sepulturas de los infieles, del resto de los fallecidos en conformidad a los códigos canónicos. La división del cementerio de Concepción tuvo sus características propias, pues se fraccionó la necrópolis a la mitad, de orientación norte a sur, ocasionando paralelamente la molestia en las familias de la elite penquista sensibilizadas con la figura de Zañartu, principalmente integrantes de la masonería local, con claras orientaciones al radicalismo e ideas progresistas en general. Las familias cercanas a la figura del difunto coronel ordenaron sacar las cruces y simbolismos católicos de las tumbas de sus antepasados, para posteriormente decorarlas con obeliscos, ángeles, ánforas, estatuas de los difuntos y por supuesto, la conocida cruz inserta dentro de un círculo, símbolo del credo protestante.

En el mismo cementerio de Concepción, según la historiadora Sol Serrano, luego de lo acontecido con el coronel Manuel Zañartu, un joven se había suicidado y fue sepultado sin la autorización parroquial. Según los antecedentes expuestos por Serrano: "Los amigos le dijeron al sacerdote que estaba fuera de su razón [el joven fallecido], pero aparecieron las cartas que había escrito antes de morir explicando su decisión...». ${ }^{60}$ Finalmente, se imponía la voluntad ciudadana de sepultación, acompañada de la gestión del Estado para que los cementerios estuviesen siempre dispuestos a la ciudadanía sin importar la condición religiosa de sus muertos.

La secularización en lo público para la ciudad de Concepción y sus localidades aledañas, alcanzó su punto álgido ante el conflicto de los cementerios. El cementerio de Concepción había sido el símbolo de toda una disputa, y, claramente, de la derrota política para el catolicismo y el ultramontanismo en todo Chile. Comenzaba a materializarse un importante cambio cultural producto de la secularización, pues la antesala a la modernidad se inmiscuía en la política, e intelectuales chilenos de la segunda mitad del siglo XIX.

\section{«MI SILENCIO Y MI PALABRA» EL OPÚSCULO DEL OBISPO DE LA CONCEPCIÓN (1871-1872)}

Las palabras de José $\mathrm{H}$. Salas quedaron manifestadas en su libro El Despojo de los Cementerios, Opúsculo del Obispo de la Concepción (1872). La obra quedó constituida por toda una síntesis de las cartas, decretos y publicaciones más relevantes en función del conflicto. Es gracias a la recopilación efectuada por el obispo Salas que es posible advertir el sentimiento de derrota ocasionado por el accionar del Gobierno hacia la Iglesia chilena, materializado en el ministro del interior, el conservador Eulogio Altamirano durante el año 1871. Salas expresó en forma detallada el agravio que a su juicio, habría sido objeto el cristianismo, 
FIGURA 3

Publicación de prensa en la cual se reflejaba el contenido del libro Los Cementerios del obispo José Hipólito Salas

(Publicidad publicada en La Libertad Católica, de marzo a diciembre de 1872)

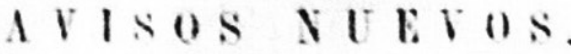 LoU CRMEYTLRIOS, POR EL OBISPO DE LA CONGEPCION.}

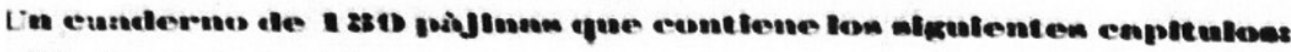

. Mi silencio i mi palabra.

I. Los hechos.

II. Mi reclamo i la enestion.

V. los cementerios ante la laviesia.

I. La Islesia i la negacion de sepultura eclesiastiea.

I. Loscementerios anle la lei espaniola.

11. Luscementerios ante has leyes patrias. I Iocumentos.-Doce piezas jusiticativas.
VIII. El principio de las invasiones.

IX. Ia interpelacion Santa-Maria.

X. E.l acuento Blest-Gana.

XI. El Decreto supremo de 21 de dieienbre.

XII. Ias objeciones.

xill. Conclusion.

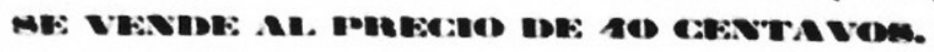

Concepeion.- I.ilreria do I. José Maria Sarrato.

Chillan.-D. Danie! Ibarrondo.

Talea.-Proh. D. Miguel IR. Prado.

Santiago.- Nimacen de $D$. Jose Maria Anrique i Cat.

Propiedad de la Imprenta de ros amitos bat. pass.;

acusando a los liberales y al gobierno de Federico Errázuriz de inconsecuencia con sus principios de respeto a la conciencia cristiana. La derrota queda expresada en la siguiente reflexión:

Esta es una espantosa tiranía i una opresion vergonzosa de la conciencia cristiana [...] Sin embargo, triste es decirlo, hai en las aseveraciones i doctrinas del Señor Ministro lo suficiente para llegar a tan increíble estremo. La lójica, como las matemáticas, es inflexible en sus procedimientos. ${ }^{61}$

Existía a juicio del obispo, aspectos en la doctrina cristiana que eran imposibles de transar. Su defensa de los valores cristianos, y por cierto, los intereses políticos y morales de la Iglesia en lo público, implicaban el desarrollo de un ejercicio reflexivo referente a la encrucijada que le significaba la transgresión del espacio sagrado. En otras palabras, el desarrollo de la secularización.

Hacia el año 1872 la polémica estaba todavía muy lejos de terminar, el periódico La Libertad Católica, en su rol defensor de los intereses de la iglesia local, persistía en el amparo valórico del discurso de Salas, y junto con él, salvaguardando los intereses eclesiásticos locales y nacionales. Corría el mes de marzo de 1872 cuando el obispo de Concepción amparado del apoyo conservador, consiguió publicar un libro con todas las ideas suscritas en el pensamiento religioso y la moral católica referente a su postura frente el actuar del gobierno y los argumentos de su causa. La publicación presenta además, una compilación de las determinaciones avaladas por el obispo Salas ante la cuestión de los cementerios. La Libertad Católica, en consecuencia, encabeza su publicación del miércoles 13 de marzo de 1872 efectuando una presentación sintética del libro Los Cementerios (1872) de su autor, el riguroso obispo de la Concepción, Dr. José Hipólito Salas. Al respecto, el periódico describe lo siguiente:

Los Cementerios por EL OBISPO DE LA CONCEPCIÓN (1) [...] He aquí un libro destinado a producir una profunda sensación i a ser leído por cuantos en Chile se ocupan de la cosa pública: amigos o enemigos de la Iglesia Católica [...] El Iltmo. señor Obispo de la Concepcion habia guardado en su larga via-crucis, mientras la impiedad lo hartaba de toda clase de insultos, un profundo silencio que no todos comprendían. El Prelado de Concepcion, decían los unos, esta mui arrepentido de su reclamo de 16 de octubre, i asustado con la descomunal gritería que esa Nota levantara, pide como Jonas que lo arrojen al abismo del silencio para calmar tan desecha tempestad. La prudencia i conciliación ha embargado su voz i paralizado su pluma. Así hablaban los tímidos i contemporizadores [...] No; decian los otros; guarda silencio porque no tiene qué responder [...] Pero, ni estos ni aquellos tenian razon [...] iQue despierten, pues, los dormidos; i que los vencedores detengan sus cantos de triunfo! La causa de la Iglesia no está perdida, ni el miedo ha paralizado los brazos de sus defensores. ${ }^{62}$

El recurso retórico de victimización ante la figura del obispo Salas, permitía generar empatía a quienes se reconocían como fervientes católicos, sin embargo, más allá del catolicismo propio los lectores, el compartir la fe no garantizaba que tuviesen adherencia a la defensa de la Iglesia en materias del caso Zañartu. Liberales, radicales e incluso conservadores católicos perfectamente podrían haber hecho

\footnotetext{
61 Salas 1878: 63
}

62 «La Libertad Católica», Concepción, 13 de marzo de 1872. 
causa común en contra del obispo en virtud del respeto hacia Zañartu, situación que se condijo al rol de los conservadores presentes en el gobierno de Federico Errázuriz, quiénes optaron por avalar las gestiones del intendente Manselli. Ante un escenario a momentos adverso para la Iglesia local, había que rescatar y sensibilizar por parte del obispo, a los lectores penquistas de finales del siglo XIX, caracterizados por poseer una mentalidad mucho más crítica, posiblemente coadyuvada por el fuerte desarrollo de la prensa ideológica en Concepción y todo el país. ${ }^{63}$

Era necesario apelar al más profundo sentimiento de conciencia católica: «los católicos por su parte lanzarán un grito de alegría al ver tan espléndidamente vindicados los derechos de la santa Iglesia de las acusaciones i calumnias que como copiosa lluvia han caído sobre sus veneradas instituciones». ${ }^{64}$ Todos estos esfuerzos se realizaron para alentar al pueblo católico a inmiscuirse del problema. De igual modo se expresaba el profundo pesar del clero penquista, pues la secularización era un fenómeno que además de ser un componente de la modernización cultural, representaba una oscura artimaña que, según la percepción religiosa, su propósito no era otro que silenciar y atacar a la Iglesia en sus fundamentos doctrinarios y políticos. Retomando la publicación del 13 de marzo de 1872, se indica lo siguiente:

Pero no solo esperimentarán los católicos una viva satisfaccion al recorrer las pajinas de este escrito, sino que hallarán en ellas un arsenal bien provisto de armas invencibles para desbaratar las objeciones i dificultades que les presente la impiedad. Aprenderán tambien, los que no lo sepan, que el asunto o cuestion de los Cementerios no es un objeto de poca importancia, como lo quieren nuestros enemigos para adormecernos traidoramente. Verán aquí que los principios en que se funda la institucion del Cementerio católico, tal cual lo quiere la Iglesia, son los principios mismos del Cristianismo, de la moral i de la civilizacion verdadera; i que no hai mas razon para cerder el campo a la incredulidad en el asunto Cementerios que no la habría en cualquiera otra de las gravísimas cuestiones que se ajitan en la época actual. ${ }^{65}$

La publicación de La Libertad Católica insiste en lo fundamental que es resguardar las doctrinas de la Fe cristiana, el nivel de importancia es tal, que los consideró como los principios fundamentales «[...] de la moral i de la civilizacion verdadera...». ${ }^{66}$ Toda la cosmovisión cristiana chilena estaba plenamente impregnada en su historicidad por la fe. No debía ser posible para la Iglesia otra concepción del mundo que no fuese la determinada por el cristianismo y la fe católica. Frente a un paradigma concéntrico como lo fue el cristianismo católico, se debía dejar en claro al Concepción de 1872 que todo aquel que estuviese distante de esta forma correcta de plantear la conducta social y ciudadana, estaba recayendo en las gravísimas cuestiones que se desarrollaban en la época contemporánea al conflicto.

La época actual, aludida por el periódico vocero del conservadurismo católico de Concepción, simbolizaba la catarsis de la Fe católica, era el desprestigio de los valores

\footnotetext{
63 Santa Cruz 2010: 57-68.

64 "La Libertad Católica», Concepción, 13 de marzo de 1872.

65 Ídem.
}

66 Ídem. fundamentales que la Iglesia profesaba, contexto en el cual, los católicos fervientes y partidarios del obispo Salas, deberían requerir de argumentos para poder revalorizar la desprestigiada Iglesia católica de Concepción. En ese esfuerzo estaba orientada la serie de publicaciones en las cuales, se explicarían la actitud adoptada por el ilustre prelado de Concepción. La Libertad Católica respecto de este punto, señaló que debían leer el opúsculo los «[...] amigos y enemigos de la Iglesia. Los primeros hallarán instrucción, consuelo i motivos para excitar su valor; los segundos, si tienen recta razon i suficiente buena fé, abrirán los ojos i confesarán la injusticia de sus pasados ataques ${ }^{67}$; lo último, claramente no ocurrió, pues como el propio obispo lo señalaba en sus cartas y publicaciones de prensa, la crítica adquiría matices fuertes. El entredicho hacia la Iglesia sería un rasgo evidente de la modernidad, en cuya directriz comenzaban a situarse sus bases en la sociedad penquista y chilena de finales del siglo XIX, marcando la trascendencia del ciudadano como centro de las preocupaciones del Estado.

Salas consideraba vital la presencia de un periódico conservador en Concepción, pues resultaba imprescindible tener un portavoz de las ideas del partido. El segundo propósito esencial del periódico era defender la integridad de la Iglesia de los ataques del radicalismo penquista, cuya ideología, según la perspectiva del obispo, pretendía extralimitar la buena fe de los católicos. La Libertad Católica continuaba siendo el principal medio para defender la causa católica, y en consecuencia, el medio oficial del obispo Salas para exponer sus ideas y las del partido. Continuando con el mensaje suscrito en el primero de los siguientes artículos que justificaban la defensa y actitud del obispo, es posible encontrar:

[...] I, gracias a Dios, no han sido ni la cobardia ni el miedo a los escritores de esas escuelas los que han detenido mi pluma. Conozco las tendencias i los principios de estos enemigos a la verdad católica i no se me oculta su táctica en las luchas del periodismo. No me turba ni me espanta la grita de los adversarios de la Iglesia. He navegado i navegaré todavía sin miedo en esta clase de mares tempestuosos. Cuando en la navegación de la vida, la justicia es la brújula i el deber el piloto, no inquietan las oleadas de las mas deshechas tormentas. ${ }^{68}$

Las palabras del propio obispo develan una defensa del orgullo propio, resultando una frustración que va más allá de toda conjetura teológica o incluso política. El obispo destinó esfuerzos en defender la trascendencia e impronta institucional que a la Iglesia le convenían; le importaba además, defender los intereses del conservadurismo por cuanto era la fuerza política de la cual, la Iglesia penquista podría obtener beneficios. Todo lo antes mencionado quedó revelado en el ya citado artículo de prensa. Al respecto, se publicó por La Libertad Católica:

[...] Las coaliciones políticas, hijas de la intriga i de viejas preocupacion anti-católicas no llevan el convencimiento a ninguna conciencia honrada ni la paz a ningún corazón católico [...] Al travez de los insultos que sin 
tasa medida me ha prodigado la prensa de mi pais que sirve al regalismo, al radicalismo, i al protestantismo... ${ }^{69}$

A lo que Salas llamó vieja preocupación anti-católica no era otra cosa sino la crítica del conservadurismo por parte de las coaliciones disidentes, las cuales independiente de sus articulaciones irónicas que pudiesen haber proliferado en la prensa radical y liberal, tenían un sentido de fortalecer el Estado, y otorgarle a la Iglesia una responsabilidad espiritual y moralizante de sus habitantes. Ello explicó el trabajo en conjunto que Estado e Iglesia desarrollaron en la Sociedad de Beneficencia de Concepción, al igual que otras existentes en el país. ${ }^{70}$

Ante el conflicto mediático de los cementerios, el obispo Salas no aludió a cabalidad el problema de fondo, el cual se originaría por el Código Civil imperante para el período. El artículo 586 dejaba en claro que todo aquello consagrado por el culto divino, «[...] se regirán por el derecho canónico, lo que importaba dar vigencia a éste en los asuntos relativos a templos y cementerios y, por lo que tocaba a los últimos, privar de sepultura eclesiástica a los que dicho derecho señalaba... $\nu^{71}$, en ese sentido, se debía impedir la sepultación de los no bautizados, excomulgados, apóstatas, y como el propio Eyzaguirre en su discurso conservador lo señalaba: «[...] los que viven en público escándalo, etc...». ${ }^{72}$ El argumento central en todo el desarrollo del problema estaba explicado a cabalidad y en forma sintética, en el mismo Código Civil vigente para mediados del siglo XIX. Todas las vicisitudes suscitadas a raíz de los cementerios debían argumentarse a partir del Código, principalmente, por constituirse en una herramienta proclive a los argumentos eclesiásticos, sin embargo, el obispo Salas no logró favorecerse de esta prueba con claridad.

Todos los esfuerzos de Salas finalmente quedaron concretados en sus dos defensas, la primera de ellas se denominó Los Cementerios (1872). Con posterioridad, pero también en el mismo año, salió a la luz El Despojo de los Cementerios Opúsculo del Obispo de la Concepción (1872). Ambos textos fueron de circulación limitada, sin embargo, en el segundo libro se incluyeron cartas con las autoridades más todos los artículos de La Libertad Católica entre los años 1871 y 1872 , en cuyos contenidos se reflejó el pensamiento del obispo Salas respecto del conflicto.

Fuera de todos los esfuerzos desarrollados por Salas, nada se podía hacer para enmendar la situación. Ya en 1883 bajo el Gobierno del presidente Domingo Santa María quedó zanjada la cuestión de los cementerios, esgrimiéndose una ley que impedía negar las exequias de difuntos en cementerios administrados por los municipios y el Estado. En el Boletín de Leyes y Decretos del Gobierno de agosto de 1883 bajo el título Inhumación de cadáveres, quedó establecido:

En los cementerios sujetos a la administracion del Estado o de las Municipalidades, no podrá impedirse, por ningún motivo, la inhumación de los cadáveres de las personas que hayan adquirido o adquieran sepulturas particulares o de familia, ni la inhumación de los

\footnotetext{
69 Ídem.

70 Ponce de León 2011: 18-377.

71 Eyzaguirre 1977: 149.

72 Ídem.
}

pobres de solemnidad [...] I por cuanto, oido el Consejo de Estado, he tenido a bien aprobarlo i sancionarlo; por tanto, promúlguese i llévese a efecto como lei de la República. ${ }^{73}$

Luego de doce años de haber transcurrido el conflicto de los cementerios, la noción de propiedad privada estaba plenamente interiorizada en la cultura chilena. La secularización había sido clave al resguardar aquellos espacios considerados públicos, pero que al mismo tiempo se tensionaban con un elemento fluctuante que por cierto, ni el obispo Salas ni menos sus detractores, lograron auscultar: a nadie que tenga un sepulcro propio se le debiese negar el permiso de sepultación, aun cuando este muriese sin la bendición de la extremaunción católica.

Si el coronel Manuel Zañartu Opazo había adquirido una propiedad en el cementerio de Concepción, necrópolis que además, estaba administrado por la Sociedad de Beneficencia de la misma ciudad, aun cuando este estuviese ubicado en el sector con la bendición canónica, no tendría fundamento alguno la idea de solicitar la autorización de inhumación al párroco de Concepción, menos, negar desde la institución religiosa las exequias de un individuo (a) cualquiera por incompatibilidad religiosa. No obstante a lo anterior, las legislaciones y los decretos existentes previos a las gestiones del presidente Santa María en 1883, no entregaban claridad respecto del proceder con aquellos difuntos fallecidos fuera de la bendición eclesiástica, independiente de la existencia del Código Civil, que incluso desde su contexto histórico parecía caracterizarse por estar obsoleto. Marco León frente a este respecto, señala: «no vemos en el siglo XIX mayores avances respecto de un cuerpo organizado de normativas sobre los cementerios. Las leyes que existían, más bien regían aspectos generales como ocurrió con la ley dictada por Ramón Freire el 31 de julio de 1823, donde nuevamente se prohibían los entierros en las iglesias... ${ }^{74}$ Por tanto, toda interpretación de parte de la Iglesia habría quedado al arbitrio de lo ya existente, o bien, con las pautas otorgadas por el Código Civil según lo revisado anteriormente.

Nuevamente la secularización le había doblado la mano a los designios de la Iglesia. La noción de propiedad privada comenzó a gestarse como una característica en la cual, era el individuo - el ciudadano, pero también el habitante en general- a quién se le estaba considerando como el centro de las preocupaciones del Estado, y la muerte no estaba distante a esa condición en tanto esta les llega a católicos y laicos por igual. La secularización coadyuvó a que finalmente el catolicismo, «[...] redefinió su concepto del espacio sagrado de la muerte como un espacio individual... $\nu^{75}$, esto, en virtud de la nueva revalorización del individuo, que en palabras de Sol Serrano: "[...] se yergue como concepto jurídico y como actor sociológico en un contexto de crecimiento demográfico, de dramática urbanización y de la aparición de la mortalidad como un problema social que el gobierno y la ciencia médica debían enfrentar ${ }^{76}$; individuo

73 «Ley de Inhumación de Cadáveres», segundo semestre de 1883. Imprenta Nacional, Calle de la Moneda 52, 1883, Santiago, p. 644.

74 León 1997: 42.

75 Serrano 2008: 222.

76 Ídem. 
y propiedad privada fueron los aspectos que desplegaron la necesidad tanto en Concepción como el resto de Chile, de reorientar lo religioso al sitial que a juicio de los radicales y rojos consideraban debía estar, en la esfera de lo privado, y en actitud respetuosa de los otros credos que comenzaron a proliferar en Chile durante toda la segunda mitad del siglo XIX. A lo que se quería llegar es a que la muerte por tratarse de un fenómeno que llegaba a todos, pudiese tener un espacio de sepultación secular, en el cual podían tener cabida todo difunto (a), independiente de su condición religiosa o moral.

En virtud de las reminiscencias suscitadas en 1883, con el decreto emitido por el gobierno antes revisado, la resistencia católica desde Santiago proliferaba nuevamente gracias a la prensa. La voz de la inconformidad estaba a cargo del Estandarte Católico, en cuyas páginas se advierten los exámenes referidos al artículo suscrito por el gobierno. Para la Iglesia, como se plantea en la investigación, el asunto de los cementerios fue un impacto que se asoció al plano moral, por tanto el recurso del llamado a la conciencia del católico resultaba ser necesario por afrontar la resistencia a su postergación de lo público. En consecuencia, con el discurso del siglo XIX, la conciencia del ciudadano católico se orientaba a servir a la patria, en la férrea unión con aquellos elementos que desde el conservadurismo se dictaminaban por estar en común acuerdo con los planteamientos de la Iglesia católica. Todo lo antes enunciado, quedó presente en las siguientes líneas:

Creemos que el decreto de nuestro Gobierno civil, fecha 11 de Agosto último, no ha sido examinado i discutido en todas sus faces [...] Por otra parte, la conciencia nos dicta que no debemos omitir nuestro pequeño continjente en la defensa de la relijion santa que profesamos, ya que es lo mas estimable i de mayor respeto para nosotros, i ya que de este modo servimos tambien directamente los altos intereses de nuestra patria, en esta ocasion con mas especialidad ligados con la suerte de la Iglesia católica en Chile [...] Emprendemos este trabajo en nuestro doble carácter de católicos i patriotas, i con la firme conviccion de que cumplimos un deber sagrado protestando enérgicamente contra los considerados i resoluciones del citado decreto, que no solo ofende con violencia los santos e inviolables derechos del catolicismo, quebrantando al efecto la Constitucion del Estado i las leyes, sino que nos daña con rudo golpe a la libertad mas preciosa i mejor garantia, la libertad de conciencia. ${ }^{77}$

El recurso del ciudadano patriota y católico se materializaba en las líneas del Estandarte Católico apuntando a un llamado a la conciencia. El intersticio del mensaje implícito en el artículo, aludía a una evocación validada por la cultura leguleya del siglo XIX, fundamentando su vinculación estática que perseguía en la hibridación Iglesia-Estado, el sostener la armonía y complicidad entre los dos poderes. El remanente instituido tras el conflicto de los cementerios procuró decantar un llamado inminente a la pluralidad que buscaba instituirse en Chile tras los procesos migratorios, acompañados de la coincidente divergencia cultural de los inmigrantes y la disidencia eventual que existía en Chile, todo ello en función de los acontecimientos concitados por el ejemplo del coronel Zañartu. La cultura chilena entre los años 1870 y 1880 se mostraba cada vez más en apertura a la pluralidad religiosa. La cultura ciudadana, más las corrientes intelectuales coadyuvadas por el positivismo, estaban cimentando lo moderno como una realidad cada vez más plausible en la mentalidad ciudadana del Chile decimonónico, que abandonaba gradualmente lo tradicional.

La secularización se desarrolló desde la perspectiva expuesta, en un proceso de cambios que engloba necesariamente el plano cultural. No es posible asociarla únicamente a un elemento jurídico o simplemente político. La muerte escapa de las cosmovisiones previas, por tanto, como fenómeno natural, le llega a católicos, disidentes, laicos y agnósticos. ${ }^{78}$ Se forjaba en consecuencia, la necesidad de establecer espacios seculares o bien, restar el componente sagrado del Cementerio Municipal de Concepción y al resto de los existentes en Chile, tal como ocurrió con posterioridad. Los cambios suscritos por la secularización, siempre entendida como un proceso previo a la modernidad, daban cuenta del trasfondo cultural que visualizaba la muerte como un blanco de la transformación simbólica propiciada por la modernidad. La muerte no era de arbitrio exclusivo para el catolicismo, esta se comenzaba a proyectar como una realidad que invitaba a discernir las necesidades culturales de los nuevos tiempos. Quedaba en ciernes la transformación de los cementerios, los cuales dejaban de ser campos santos, para convertirse en las necrópolis con las connotaciones modernas mediante las cuales, la muerte se posiciona en la actualidad.

La percepción de postergación resultaba notoria para el catolicismo, a tal extremo que en 1884 el arzobispado de Santiago determinó publicar sus reflexiones respecto de las distintas materias públicas en las cuales, la Iglesia ya no tendría más injerencias de forma exclusiva. La Pastoral Colectiva Sobre Relaciones entre Iglesia i Estado, publicada en 1884 bajo las ordenanzas de los obispados existentes en Chile, planteaba una síntesis asociada a cada una de las etapas de conflicto entre ambas instituciones. El documento abre la reflexión señalando:

La tempestad que se ha desencadenado en ésta época nada respeta de lo que ha sido siempre objeto de profunda veneracion en todos los pueblos cristianos: se niega a Dios, eliminándolo del órden público, a nombre de la pretendida soberanía absoluta del hombre, en el gobierno de la vida social; se pervierten las costumbres colocando bajo el amparo de la lei instrucciones tan inmorales como el matrimonio civil; se ofende a la relijion expulsándola de las leyes, del gobierno, de la enseñanza por medio del ateismo político; se ataca a la Iglesia en su propiedad con el despojo violento e ilegal de muchos de sus cementerios adquiridos de justo título i con el cercenamiento injusto de las rentas eclesiásticas; se atropellan los derechos de la conciencia relijiosa, impidiendo a los católicos sepultarse en tierra sagrada en conformidad a sus creencias, a sus justas aspiraciones i a los preceptos de la relijion; i por fin, se ha llevado la injuria hasta el trono mismo del Vicario de Jesucristo, rompiendo, con el acto inconstitucional i ofensivo de la expulsion de su augusto representante, la tradicion de amor i veneracion para con su sagrada

77 «El Estandarte Católico», Santiago, 10 de diciembre de 1883.

78 Ariés 2000: 36-42. 
persona que habian conservado como timbre de honor todos los gobiernos de Chile. ${ }^{79}$

La figura del desplazamiento de Dios se presenta, en este apartado, a modo de consecuencia ante una inmoralidad religiosa. En otras palabras, se trataba de una ausencia de la moral en la sociedad chilena que según el pensamiento católico implicaba una total deserción de Dios en el escenario público. La secularización para la Iglesia se comprendió desde la voz auspiciada por el clero, tras auscultarse una inmoralidad en la sociedad chilena que no consideraba los valores adscritos a una patria católica, por tanto, las voces clericales oficiales comienzan a plantear la expulsión de Dios en las leyes como figura central, asociada al concepto de ateísmo político. Considerándose este escenario perjudicial para el catolicismo, se configura la pregunta de Sol Serrano: ¿Qué hacer con Dios en la República?, pues la Iglesia no logró comprender - que ya sea desde el escenario de la muerte, más las distintas reglamentaciones laicas aprobadas para quienes no profesaban el catolicismo- las dinámicas propias de una secularización que pretendía situar la preocupación del Estado en materias ciudadanas. No hubo desde esta cosmovisión, un abandono de Dios, por el contrario, se trató de una modernidad religiosa que fue abriendo camino a nuevas formas de religiosidad, principalmente protestante, como también a la revalorización del catolicismo en los ciudadanos; según Jean-Pierre Bastian, se trató de "...la pluralización religiosa, es sin lugar a dudas el rasgo común de la modernidad religiosa en el espacio de la latinidad $» .^{80}$

El Estado de Chile debía tomar partido respecto de esta reconfiguración de lo religioso, antecedente que proyectó en la muerte un cambio conducente en la secularización de los cementerios. El rito mortuorio a partir de esta percepción, se configuró bajo un referente de modernidad transformadora, pues Manuel Zañartu Opazo, aun cuando desde la perspectiva moralista católica estaba incurriendo en una falta, se definió a sí mismo como un católico, pese a que su sociabilidad no estaba tan asociada a la Iglesia como a otras entidades tales como la masonería, los círculos laicos y oligarcas de Concepción.

\section{CONCLUSIONES}

A modo de síntesis, la muerte del coronel Zañartu implicó una fuerte recriminación hacia la institución eclesiástica. Más allá de las intrigas evidentes, se demostró que ya la armonía entre el Estado y la Iglesia católica con su protagonismo en el escenario público estaban en una importante crisis. Según Marco León, tanto la ideología liberal-republicana, como también «[...] otros movimientos que tomaron forma durante el siglo XIX como el racionalismo, el positivismo y el evolucionismo; se encargaron paulatinamente de ir socavando el peso social y cultural de la Iglesia católica en el país». ${ }^{81} \mathrm{~A}$ partir de esta premisa, se configurará la postergación católica en las preocupaciones públicas, dejando tres décadas del legado colonial dispuesto por

79 «Pastoral Colectiva sobre las Relaciones entre la Iglesia i el Estado", 1884, Imprenta de El Correo de Ramón Varela, Teatinos, n³9, Santiago, pp. 3-4.

80 Bastián 1990: 11

81 León 2013: 489. el Estado indiano, materializado por la influencia social y sistémica entre el aparato administrativo y la Iglesia. El Estado republicano que a su vez utilizaba lo religioso como un instrumento para atender el orden y la moral del país, debía abrir caminos a la diversidad en una ciudad como Concepción. Los aires de modernidad -en apariencia incipientes, y todavía como un proceso a largo plazoestaban abriendo espacios para la muerte en disidencia.

La secularización de la muerte fue una herida crucial para el catolicismo de Concepción, demarcada por una postergación sociológica que elevó los valores y virtudes de un personaje como Manuel Zañartu por sobre la ilusión moral fuertemente criticada por la Iglesia de Concepción. Todo este contexto de menoscabo para la percepción eclesiástica, configuraba el antecedente de postergación incomprendido para el catolicismo latinoamericano. La segunda mitad del siglo XIX tanto en Chile como en el resto del continente, según Ricardo Krebs, traería consecuencias en los distintos estamentos socioeconómicos, los cuales se alejarían del catolicismo para efectuar, desde una primera instancia, una transposición de lo religioso al ámbito privado, tal y como lo planteaban los liberales, radicales y masones, quienes "[...] estaban convencidos de que la religión era un asunto de la conciencia privada, de que debía haber libertad religiosa y tolerancia y de que había que excluir la Iglesia de la vida pública». ${ }^{82}$ El dinamismo social inserto en el paradigma de la secularización habría sido el responsable de resinificar toda una estructura cultural religiosa ligada a la muerte, que en base a la burocracia regalista rectora de los procesos históricos del siglo XIX, habrían mermado los valores tradicionales inmersos en el catolicismo chileno. La modernidad se materializaba, afectando a los procesos vitales como la muerte en el plano religioso.

La muerte como un componente de la cultura ciudadana se había modernizado, y en virtud de ese antecedente, la legislación requería de una revisión exhaustiva para instituir un libre acceso a los cementerios en los cuales, el Estado y los municipios tenían directa injerencia administrativa. Las instituciones laicistas como la Masonería chilena de la segunda mitad del siglo XIX pretendían abrir el campo religioso y secular a la ciudadanía disidente, la cual gradualmente se estaba insertando con la inmigración europea en todo el sur de Chile.

La molestia en los habitantes de Concepción ante la prohibición del obispo se tradujo en un multitudinario funeral, el cual según lo descrito por la prensa revisada, fue una muestra clave del respeto y apego a un personaje político como Zañartu, que además de sus hazañas en las luchas independentistas se destacó luego de su retiro, por participar en distintas actividades e instituciones públicas para la ciudad, desde ser administrador de la municipalidad, hasta presidir la Sociedad de Beneficencia de Concepción hasta 1871. De toda esta coyuntura, la prensa liberal sacó sus mejores argumentos para atacar al conservadurismo, mientras que la contraparte, no hacía más que defender lo que consideraban era un actuar legal de la Iglesia, también aludiendo al a la responsabilidad moral eclesiástica respecto de un Estado católico.

La prensa liberal moderna se configuraba «[...] así misma por su pretensión informativa $y$, consecuente

\footnotetext{
82 Krebs 2002: 300.
} 
con ello, por la generación de un mercado noticioso y de empresas suficientemente capaces para competir en él...» ${ }^{83}$; ante dichos cambios, la Iglesia debía resistir en sus argumentaciones tradicionales, apelando al sentido cultural y tradicional del Estado católico. El conservadurismo por otro lado, intentaba replegar la bandera por la defensa de los haberes de la Iglesia. El clero utilizaba una y otra vez los recursos de la fe católica más su preeminencia en la vida política y soberana del Chile de finales del siglo XIX.

Tanto los conservadores como toda la institucionalidad eclesiástica presente en la Iglesia, desarrollaron la cosmovisión de Chile en función de un Estado Católico. En dicho sentido, la muerte como un fenómeno natural padecida por un ícono patriótico como finalmente se convirtió Manuel Zañartu, obedeció a una contrapartida generada por el cambio cultural de la época: una sociedad más modernizada, con un espectro cultural y de trascendencia social que prescindía cada vez más en materias de lo público del paradigma religioso.

\section{BiBLIOGRAFÍA}

Araneda, F. 1963. El Obispo José Hipólito Salas. Santiago: Universidad Católica de Chile.

Ariès, P. 2000. Morir en Occidente desde la Edad Media hasta la actualidad. Buenos Aires: AH.

Bastián, J. 1990. Protestantes, Liberales y Francmasones. Sociedades de ideas y modernidad en América Latina, siglo XIX. México DF: Fondo de Cultura Económica.

Campos, F. 1989. Historia de Concepción 1550-1988. Santiago: Universitaria.

Casanueva, F. 2002. Prensa y Periodismo en Concepción. Recopilaciones y apuntes para su historia 1833-2000. Concepción: Universidad Católica de la Santísima Concepción.

Castillo Rojas, V. 2014. "Libertad y autoridad, república y religión. El debate público en Chile a fines del siglo XIX», en A. M. Stuven (ed.), La Religión en la esfera pública chilena: ¿Laicidad o Secularización?: 215-237. Santiago: Universidad Diego Portales.

Collier, S. 2005. Chile la construcción de una República (1830-1865). Santiago: Pontificia Universidad Católica de Chile.

Elgueta Reyes, R. 2012. "iTemblad oligarcas chilenos! El proceso de secularización y los sectores obreros en Concepción (1860-1890)». Tiempo y Espacio 28: 77-106.

Estefane Jaramillo, A. 2004. «Un alto en el camino para saber cuántos somos... Los censos de población y la construcción de las lealtades nacionales. Chile, siglo XIX». Historia 37 vol. I: 33-59.

Eyzaguirre, J. 1977. Historia de las instituciones políticas y sociales de Chile. Santiago: Universitaria.
Fernández, M. 1989. Historia del cementerio de Concepción desde 1823 hasta 1989. Concepción: SEMCO.

Jakcsić, I. y Serrano, S. 2011. «El gobierno y las libertades. La ruta del liberalismo chileno en el siglo XIX», en I. Jaksić y E. Posada (ed.), Liberalismo y poder. Latinoamérica en el siglo XIX: 177-206. Santiago: Fondo de Cultura Económica.

Kaufmann Salinas, S. 2014. "El estatuto de las creencias religiosas en el espacio público: desafíos a la noción de tradución», en A. M. Stuven (ed.), La Religión en la esfera pública chilena: ¿Laicidad o Secularización?: 27-50. Santiago: Universidad Diego Portales.

Krebs, R. (com.). 1981. Catolicismo y Laicismo. Las bases doctrinarias del conflicto entre la Iglesia y el Estado en Chile 1865-1885. Santiago: Pontificia Universidad Católica de Chile.

León, M. 1997. Sepultura Sagrada, tumba profana. Los espacios de la muerte en Santiago de Chile 1883-1932. Santiago: LOM.

León, M. 2005. Una digna morada para el Altísimo. Evolución histórica y espacios de conmemoración en la Catedral de Santiago de Chile. Santiago: Seminario Pontificio Mayor.

Medina, A. 1997. Monseñor José Hipólito obispo de Concepción. Coraje y coherencia al servicio de la fe. Concepción: Universidad Católica de la Santísima Concepción.

Moscoso, P. 2006. «La Cuestión del Sacristán: Historia en diez actos», en J. L. Ossa (ed.), Historias del siglo XIX: 131-136. Santiago: Vergara.

Pacheco, A. 2003. Economía y Sociedad en Concepción Siglo XIX. Sectores Populares Urbanos, 1800-1885. Concepción: Universidad de Concepción.

Palacios Roa, A. 2006. «Muerte e Intolerancia Religiosa: La influencia masónica en el establecimiento de los cementerios laicos». Boletín de Historia y Geografía 20: 115-132.

Peralta, P. 2007. iChile tiene fiesta! El origen del 18 de septiembre 1810-1837. Santiago: LOM.

Ponce de León, M. 2011. Gobernar la Pobreza. Prácticas de caridad y beneficencia en la ciudad de Santiago 1830-1890. Santiago: Universitaria.

Prado, J. 2007. La estampida de los fieles. Los censos religiosos y la evolución religiosa en Chile. Valparaíso: El Alba.

Salas, J. 1872. El Despojo de los Cementerios Opúsculo del Obispo de la Concepción. Santiago: Imprenta del Correo.

Salinas Araneda, C. 2009. "Las relaciones Iglesia-Estado en Chile en el siglo XIX» en M. Sánchez (dir.), Historia de la Iglesia en Chile: Los nuevos caminos Ia Iglesia y el Estado: t. III, 231-277. Santiago: Universitaria.

Santa Cruz, E. 2010. La prensa chilena en el siglo XIX. Patricios, letrados, burgueses y plebeyos. Santiago: Universitaria.

Serrano, S. 2008. ¿Qué hacer con Dios en la República? Política y secularización en Chile (1845-1885). Santiago: Fondo de Cultura Económica.

Veyne, P. 1984. Como se escribe la historia. Foucault revoluciona la historia. Madrid: Crítica.

Villalobos, S. 2012. Estudios y ensayos en torno a la historia de Chile. Santiago: Universitaria.

83 Santa Cruz 2010: 56. 